\title{
Exploration of phylogeography of Monacha cantiana s.l. continues: the populations of the Apuan Alps (NW Tuscany, Italy) (Eupulmonata, Stylommatophora, Hygromiidae)
}

\author{
Joanna R. Pieńkowska', Giuseppe Manganelli², Folco Giusti², Debora Barbato², \\ Alessandro Hallgass², Andrzej Lesicki'
}

I Department of Cell Biology, Institute of Experimental Biology, Faculty of Biology, Adam Mickiewicz University in Poznan; Umultowska 89, 61-614 Poznań, Poland 2 Dipartimento di Scienze Fisiche, della Terra e dell'Ambiente, Universitá di Siena, Via Mattioli 4, 53100 Siena, Italy

Corresponding author: Andrzej Lesicki (alesicki@amu.edu.pl)

Academic editor: Eike Neubert | Received 12 November 2018 | Accepted 11 December 2018 | Published 9 January 2019

http://zoobank.org/F76A43CE-D785-409C-A0F8-08D6B1907E8D

Citation: Pieńkowska JR, Manganelli G, Giusti F, Barbato D, Hallgass A, Lesicki A (2019) Exploration of phylogeography of Monacha cantiana s.l. continues: the populations of the Apuan Alps (NW Tuscany, Italy) (Eupulmonata, Stylommatophora, Hygromiidae). ZooKeys 814: 115-149. https://doi.org/10.3897/zookeys.814.31583

\begin{abstract}
Two new lineages CAN-5 and CAN-6 were recognised in four populations of Monacha cantiana (Montagu, 1803) s.l. from the Italian Apuan Alps by joint molecular and morphological analysis. They are different from other M. cantiana lineages known from English, Italian, Austrian and French populations, i.e. CAN-1, CAN-2, CAN-3 and CAN-4, as well as from the other Italian Monacha species used for comparisons ( $M$. parumcincta and $M$. cartusiana). Although a definite taxonomic and nomenclatural setting seems to be premature, we suggest that the name or names for these new lineages as one or two species should be found among $19^{\text {th }}$ century names (Helix sobara Mabille, 1881, H. ardesa Mabille, 1881, H. apuanica Mabille, 1881, H. carfaniensis De Stefani, 1883 and H. spallanzanii De Stefani, 1884).
\end{abstract}

\section{Keywords}

16SrDNA, COI, H3, ITS2, molecular features, shell and genital structure, species distribution

Copyright Joanna R. Pieńkowska et al. This is an open access article distributed under the terms of the Creative Commons Attribution License (CC BY 4.0), which permits unrestricted use, distribution, and reproduction in any medium, provided the original author and source are credited. 


\section{Introduction}

Study of the phylogeography of the Monacha cantiana (Montagu, 1803) s.l. by joint molecular and morphological analysis revealed a number of cryptic lineages, some of which might deserve distinct taxonomic status.

Examination of a first group of English, Italian, Austrian and French populations showed that it consisted of at least four distinct lineages (CAN-1, CAN-2, CAN-3, CAN-4) (Pieńkowska et al. 2018). One of these lineages (CAN-1) included most of the UK ( 5 sites) and Italian ( 5 sites) populations examined. Three other lineages were represented by populations from two sites in northern Italy (CAN-2), three sites in northern Italy and Austria (CAN-3) and two sites in south-eastern France (CAN-4). A taxonomic and nomenclatural setting is only currently available for CAN-1 and CAN-4. The lineage CAN-1 corresponds to the true M. cantiana (Montagu, 1803) because it is the only one that includes topotypical English populations. The lineage CAN-4 is attributed to $M$. cemenelea (Risso, 1826), for which a neotype has been designated and deposited. A definitive frame for the other two has been postponed because it requires much more research.

We have now studied some populations from the Apuan Alps at the north-western extremity of Tuscany, a well-known hotspot of diversity and endemism (Lanza 1997; Biondi et al. 2013; Garbari and Bedini 2014; Carta et al. 2017; Orsenigo et al. 2018). Molecular study revealed two more lineages (CAN-5 and CAN-6), molecularly distinct from each other and from all the others, but morphologically indistinguishable from each other and only slightly distinguishable from all the other lineages of $M$. cantiana.

\section{Material and methods}

\section{Taxonomic sample}

Four new populations of Monacha cantiana s.l. were considered in our analysis of their molecular and morphological (shell and genitalia structure) variability (Table 1) and compared with the other M. cantiana lineages (Pieńkowska et al. 2018). The sequences deposited in GenBank were also considered for the molecular analysis. Two other Monacha species were used for molecular comparison (Monacha cartusiana (Müller, 1774)) and for morphological and molecular comparison (M. parumcincta (Rossmässler, 1834)).

\section{Materials examined}

New materials examined are listed as follows, when possible: geographic coordinates of locality, locality (country, region, site, municipality and province), collector(s), date, number of specimens with name of collection where materials are kept in parenthesis (Table 1). The materials are kept in the F. Giusti collection (FGC; Dipartimento di 
Scienze Fisiche, della Terra e dell'Ambiente, Università di Siena, Italy). The materials used for comparison have already been described (see Pieńkowska et al. 2018: table 1) and is now supplemented with some new nucleotide sequences (Table 2).

\section{DNA extraction, amplification and sequencing}

DNA extraction, amplification and sequencing methods are described in detail in our previous paper (Pieńkowska et al. 2018).

\section{Phylogenetic inference}

Two mitochondrial and two nuclear gene fragments were analysed, namely cytochrome c oxidase subunit 1 (COI), 16S ribosomal DNA (16SrDNA), histone $3(\mathrm{H} 3)$ and an internal transcribed spacer of rDNA (ITS2), respectively. All new sequences were deposited in GenBank (Tables 1, 2). The COI, 16SrDNA, H3 and ITS2 sequences obtained from GenBank for comparisons are listed in Table 3.

The sequences were edited by eye using the programme BIOEDIT, version 7.2.6 (Hall 1999). Alignments were performed using CLUSTAL W (Thompson et al. 1994) implemented in MEGA 7 (Kumar et al. 2016). The COI and H3 sequences were aligned according to the translated amino acid sequences. The ends of all sequences were trimmed. The lengths of the sequences after trimming were $591 \mathrm{bp}$ for COI, 355 positions for $16 \mathrm{SrDNA}, 315 \mathrm{bp}$ for $\mathrm{H} 3$ and 496 positions for ITS2. The sequences were collapsed to haplotypes (COI and $16 \mathrm{SrDNA})$ and to common sequences ( $\mathrm{H} 3$ and ITS2) using the programme ALTER (Alignment Transformation EnviRonment) (Glez-Peña et al. 2010). Gaps and ambiguous positions were removed from alignments prior to phylogenetic analysis. Mitochondrial (COI and $16 \mathrm{SrDNA}$ ) and nuclear (H3 and ITS2) sequences were combined (Table 4) before phylogenetic analysis. Finally, the sequences of COI, 16SrDNA, H3 and ITS2 were combined (Table 4) for Maximum Likelihood (ML) and Bayesian inference (BI). Before doing so, uncertain regions were removed from 16SrDNA alignment with the GBLOCKS 0.91b (Castresana 2000; Talavera and Castresana 2007) using parameters for relaxed selection of blocks. This procedure shortened 16SrDNA sequences from 355 to 275 positions.

The sequences of COI obtained in this study together with other sequences from GenBank were analysed by the genetic distance Neighbour-Joining method (Saitou and Nei 1987) implemented in MEGA7 using the Kimura two-parameter model (K2P) for pairwise distance calculations (Kimura 1980). Maximum Likelihood (ML) analyses were then performed with MEGA 7. Monacha cartusiana and Monacha parumcincta were added as outgroup species in each analysis. For ML analysis of combined sequences, the following best nucleotide substitution models were specified according to the Bayesian Information Criterion (BIC): HKY+G (Hasegawa et al. 1985; Kumar et al. 2016) for COI and 16SrDNA combined sequences of 879 positions (591 COI + 288 16SrDNA), TN92+G 


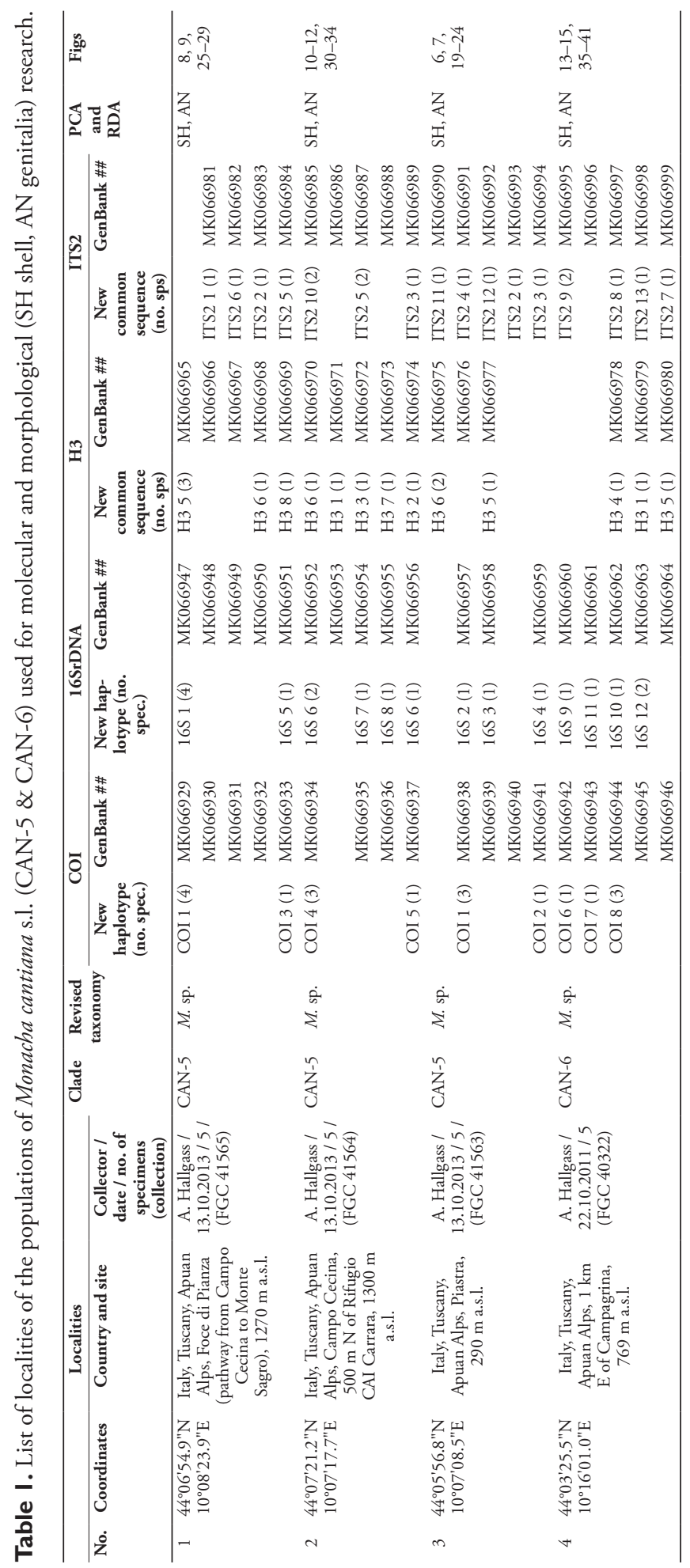


Table 2. New ITS2 sequences obtained from the specimens of Monacha cantiana s.l. (CAN-2 to CAN4) and $M$. parumcincta (PAR) used for molecular research. Number of localities after Pieńkowska et al. (2018). Earlier data on other sequences (COI, 16SrDNA, H3 and ITS2) from these localities were published by Pieńkowska et al. (2018).

\begin{tabular}{|c|c|c|c|c|c|c|c|c|}
\hline \multicolumn{4}{|c|}{ Localities } & \multirow[t]{2}{*}{ Clade } & \multirow{2}{*}{$\begin{array}{l}\text { Revised } \\
\text { taxonomy }\end{array}$} & \multicolumn{3}{|c|}{ ITS2 } \\
\hline No. & Coordinates & Country and site & $\begin{array}{l}\text { Collector / date / } \\
\text { no. of specimens } \\
\text { (collection) }\end{array}$ & & & $\begin{array}{c}\text { New } \\
\text { common } \\
\text { sequence }\end{array}$ & $\begin{array}{l}\text { No. } \\
\text { Spec. }\end{array}$ & $\begin{array}{c}\text { GenBank } \\
\# \#\end{array}$ \\
\hline 12 & $\begin{array}{l}45^{\circ} 11^{\prime} 59.85^{\prime \prime N} \\
10^{\circ} 58^{\prime} 49.30^{\prime \prime} \mathrm{E}\end{array}$ & $\begin{array}{l}\text { Italy, Venetum, Sorgà } \\
\text { (Verona) }\end{array}$ & $\begin{array}{l}\text { A. Hallgass / } 09.2012 \\
\text { / } 6 \text { (FGC 42964) }\end{array}$ & CAN-2 & M. cantiana & ITS2 14 & 1 & MK067000 \\
\hline 15 & $\begin{array}{l}44^{\circ} 22^{\prime} 09.98^{\prime \prime} \mathrm{N} \\
11^{\circ} 15^{\prime} 11.28^{\prime \prime} \mathrm{E}\end{array}$ & $\begin{array}{l}\text { Italy, Emilia Romagna, } \\
\text { along Fiume Setta, } \\
\text { upstream its confluence } \\
\text { with Fiume Reno (Sasso } \\
\text { Marconi, Bologna) }\end{array}$ & $\begin{array}{l}\text { A. Hallgass / 09.2012 } \\
\text { / } 3 \text { (FGC 42977) }\end{array}$ & CAN-3 & $M$. sp. & ITS2 15 & 1 & MK067001 \\
\hline 17 & $\begin{array}{l}48^{\circ} 15^{\prime} 25.50^{\prime \prime} \mathrm{N} \\
16^{\circ} 30^{\prime} 46.38^{\prime \prime} \mathrm{E}\end{array}$ & $\begin{array}{l}\text { Austria, Breitenlee, } \\
\text { abandoned railway } \\
\text { station }\end{array}$ & $\begin{array}{c}\text { M. Duda / 09.2015 / } \\
3 \text { (FGC 44020) }\end{array}$ & CAN-3 & M. sp. & ITS2 16 & 1 & MK067002 \\
\hline 18 & $\begin{array}{l}43^{\circ} 46^{\prime} 11.79^{\prime \prime} \mathrm{N} \\
07^{\circ} 22^{\prime} 21.50^{\prime \prime} \mathrm{E}\end{array}$ & $\begin{array}{c}\text { France, Alpes- } \\
\text { Maritimes, Vallée de } \\
\text { Peillon, Sainte Thecle }\end{array}$ & $\begin{array}{c}\text { A. Hallgass / } \\
24.10 .2011 / 5 \text { (FGC } \\
40320)\end{array}$ & CAN-4 & M. cemenelea & $\begin{array}{l}\text { ITS2 } 17 \\
\text { ITS2 } 18\end{array}$ & $\begin{array}{l}1 \\
1\end{array}$ & $\begin{array}{l}\text { MK067003 } \\
\text { MK067004 }\end{array}$ \\
\hline 24 & $\begin{array}{l}40^{\circ} 13^{\prime} 25.49^{\prime \prime} \mathrm{N} \\
15^{\circ} 52^{\prime} 17.07^{\prime \prime} \mathrm{E}\end{array}$ & $\begin{array}{l}\text { Italy, Basilicata, along } \\
\text { the road from Moliterno } \\
\text { to Fontana d'Eboli } \\
\text { (Moliterno, Potenza) }\end{array}$ & $\begin{array}{l}\text { A. Hallgass / } 2012 \text { / } 5 \\
\text { (FGC 42962) }\end{array}$ & PAR & M. parumcincta & ITS2 19 & 1 & MK067005 \\
\hline
\end{tabular}

(Tamura 1992; Kumar et al. 2016) for H3+ITS2 combined sequences of 812 positions (315 H3 + 497 ITS2), and GTR+I+G (Nei and Kumar 2000; Kumar et al. 2016) for $\mathrm{COI}+16 \mathrm{SrDNA}+\mathrm{H} 3+\mathrm{ITS} 2$ combined sequences with a total length of 1677 positions (591 COI + 275 16SrDNA + 315 H3 + 496 ITS2). Bayesian analysis was conducted with the MRBAYES 3.1.2 (Ronquist and Huelsenbeck 2003) using the same evolution model as for ML calculation. The GTR substitution model (Nei and Kumar 2000; Kumar et al. 2016), assuming a gamma distributed rate variation $(+G)$ allowing for some sites to be evolutionarily invariable $(+\mathrm{I})$, was identified as the best-fit substitution model using JMODELTEST2 (Darriba et al. 2012). Four Monte Carlo Markov chains were run for one million generations, sampling every 100 generations (the first 250,000 trees were discarded as 'burn-in'). This gave us a 50\% majority rule consensus tree. In parallel, Maximum Likelihood (ML) analysis was performed with MEGA7 (Kumar et al. 2016) and calculated bootstrap values were mapped on the $50 \%$ majority rule consensus Bayesian tree.

The haplotype network was inferred with NETWORK 5.0.0.1 to reflect all relationships between COI and 16SrDNA haplotypes. During the analysis, a median-joining calculation implemented in NETWORK 5.0.0.1 was used (Bandelt et al. 1999).

\section{Morphological study}

Seventy-eight specimens of seven clades (six lineages of $M$. cantiana s.l.: CAN-1, CAN-2, CAN-3, CAN-4, CAN-5 and CAN-6; one lineage of $M$. parumcincta) were considered for shell variability (see Table 1 and Pieńkowska et al. 2018). Shell variabil- 


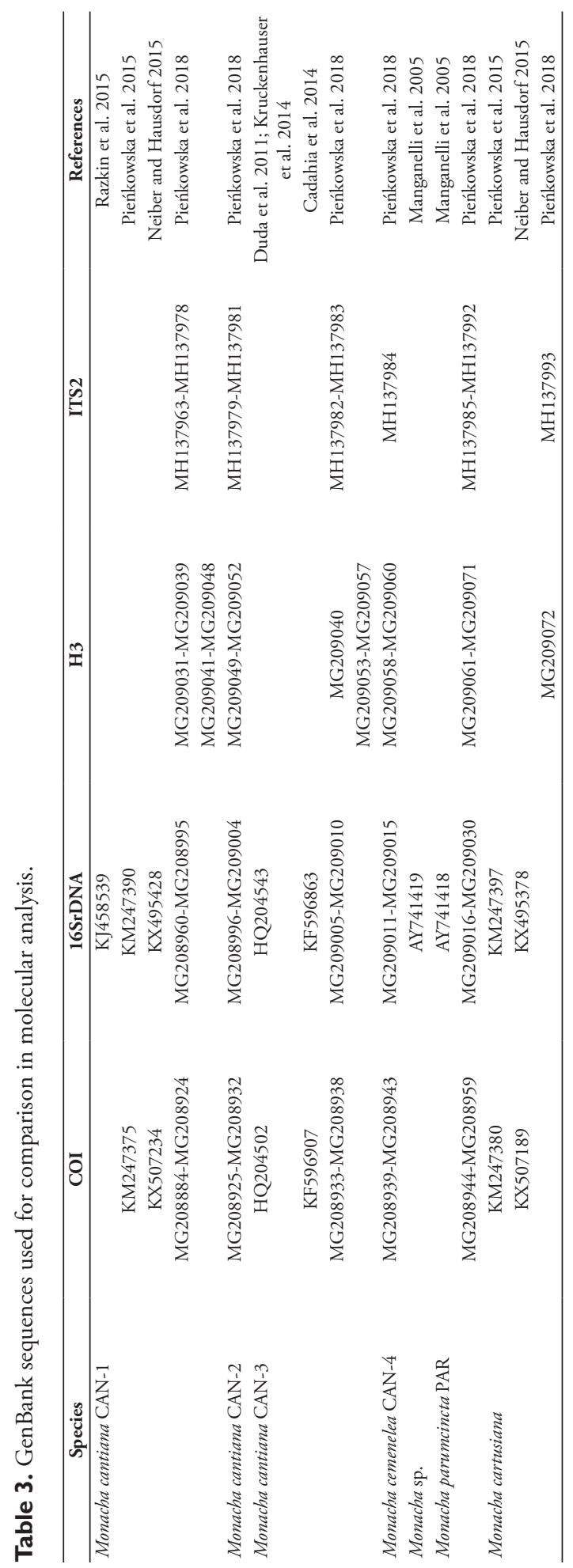


ity was analysed randomly choosing five adult specimens from each population, when possible. Twelve shell variables were measured to the nearest $0.1 \mathrm{~mm}$ using ADOBE PHOTOSHOP 7.0.1 on digital images of apertural and umbilical standard views taken with a Canon EF $100 \mathrm{~mm}$ 1:2.8 L IS USM macro lens mounted on a Canon F6 camera: AH aperture height, AW aperture width, LWfW last whorl final width, LWmW last whorl medial width, $\mathrm{LWaH}$ height of adapical sector of last whorl, $\mathrm{LWmH}$ height of medial sector of last whorl, PWH penultimate whorl height, PWfW penultimate whorl final width, PWmW penultimate whorl medial width, SD shell diameter, SH shell height, UD umbilicus diameter (see Pieńkowska et al. 2018: fig. 1).

Seventy-five specimens of seven clades (all lineages of $M$. cantiana s.l. plus one lineage of $M$. parumcincta) were analysed for anatomical variability (see Table 1 and Pieńkowska et al. 2018). Snail bodies were dissected under the light microscope (Wild M5A or Zeiss SteREO Lumar V12). Anatomical details were drawn using a Wild camera lucida. Acronyms: BC bursa copulatrix, BW body wall, DBC duct of bursa copulatrix, DG digitiform glands, E epiphallus (from base of flagellum to beginning of penial sheath), F flagellum, FO free oviduct, GA genital atrium, OSD ovispermiduct, $\mathrm{P}$ penis, $\mathrm{V}$ vagina, VA vaginal appendix (also known as appendicula), VAS vaginal appendix basal sac, VD vas deferens. Six anatomical variables (DBC, E, F, P, V, VA) were measured using a calliper under a light microscope $(0.01 \mathrm{~mm})$ (see Pieńkowska et al. 2018: fig. 2).

Detailed methods of multivariate ordination by Principal Component Analysis (PCA) and Redundancy Analysis (RDA), performed on the original shell and genitalia matrices as well as on the Z-matrices (shape-related matrices), are described in a previous paper (Pieńkowska et al. 2018).

Differences between species for each shell and genital character were assessed through box-plots and descriptive statistics. Significance of differences (set at $p \leq 0.01$ ) was obtained using analysis of variance (ANOVA); when the test proved significant, an adjusted posteriori pair-wise comparison between pairs of species was performed using Tukey's honestly significant difference (HSD) test. All variables were log transformed before analysis.

\section{Results}

\section{Molecular study}

Eighteen sequences of each mitochondrial gene fragment (COI and 16SrDNA) as well as 16 and 25 sequences of nuclear gene fragments (H3 and ITS2, respectively) were deposited in GenBank as MK066929-MK066946 (COI), MK066947-MK066964 (16SrDNA), MK066965-MK066980 (H3) and MK066981-MK067005 (ITS2). Eight COI and 12 16SrDNA haplotypes were recognised among them (Table 1). Eight $\mathrm{H} 3$ (Table 1) and 19 ITS2 (Tables 1, 2) common nucleotide sequences were also established. ML trees for combined sequences of mitochondrial COI and 16SrDNA (Fig. 1, Table 4) and of nuclear H3 and ITS2 (Fig. 2, Table 4) gene fragments, as well as the 


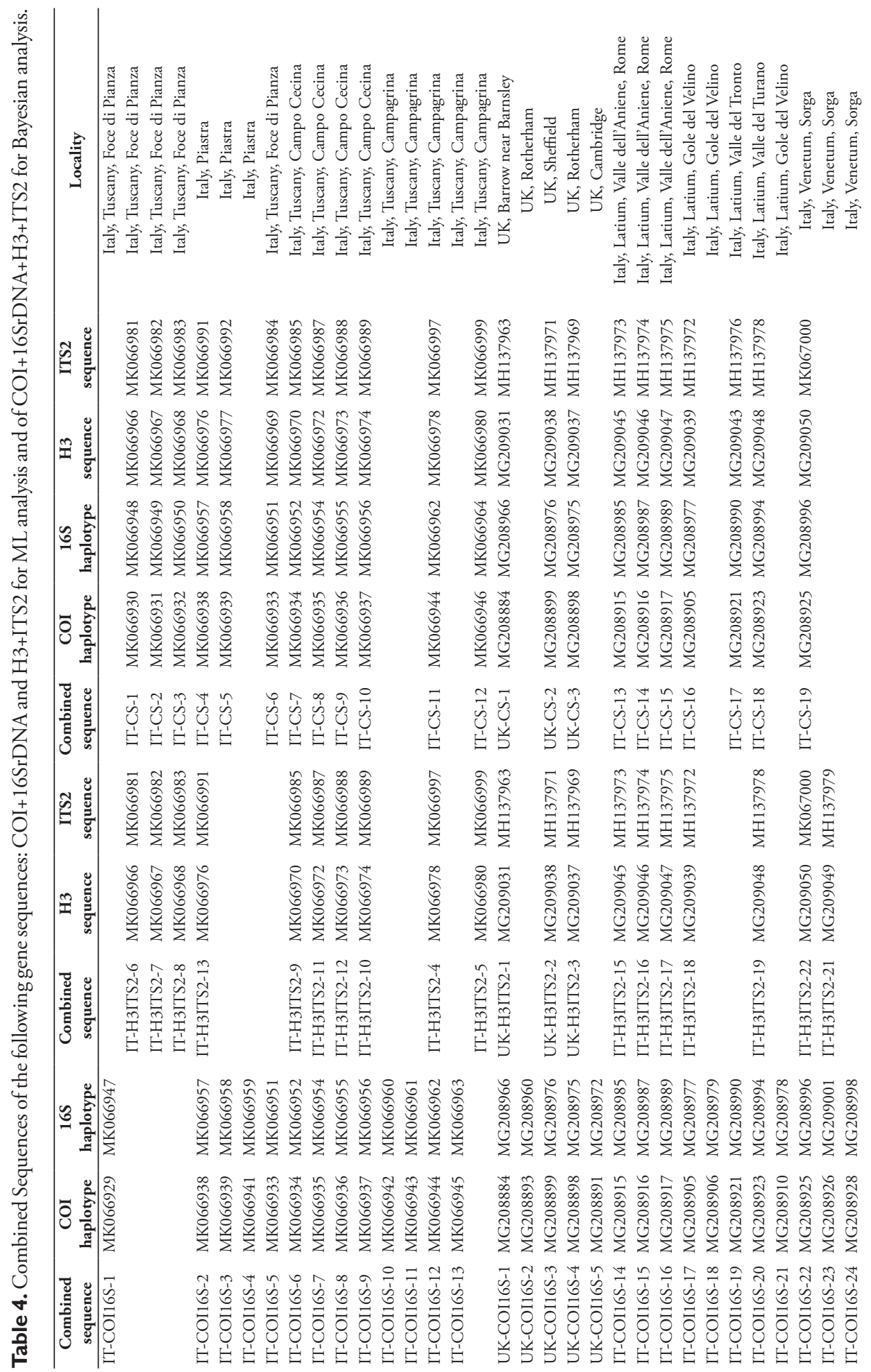




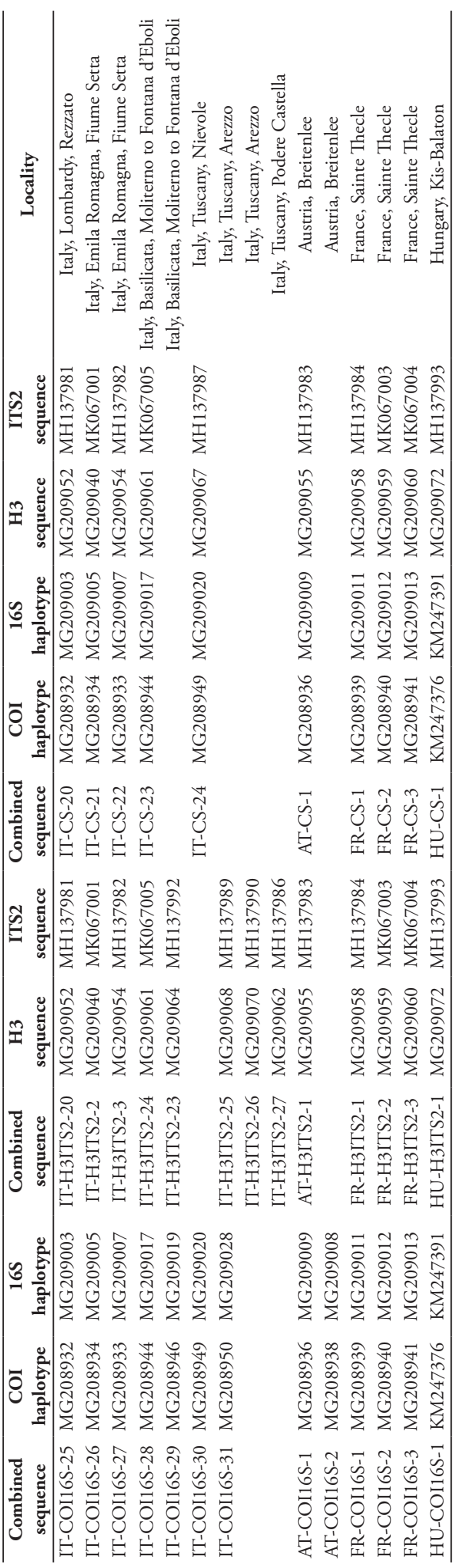




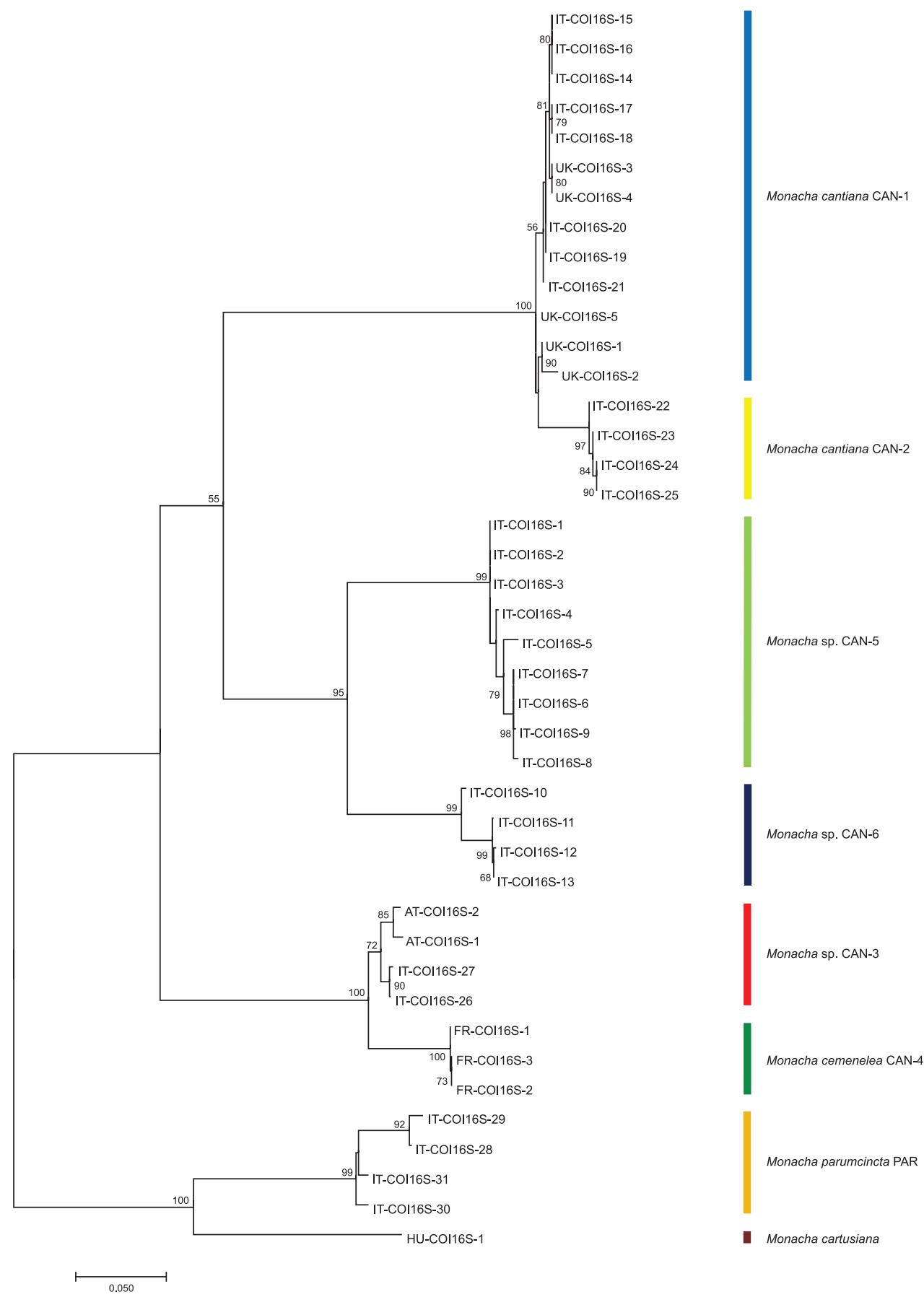

Figure I. Maximum Likelihood (ML) tree of combined COI and 16SrDNA haplotypes of Monacha cantiana s.l. (see Table 4). Numbers next to the branches indicate bootstrap support above $50 \%$ calculated for 1000 replicates (Felsenstein 1985). The tree was rooted with M. cartusiana and M. parumcincta combined sequences obtained from GenBank (Table 4). 


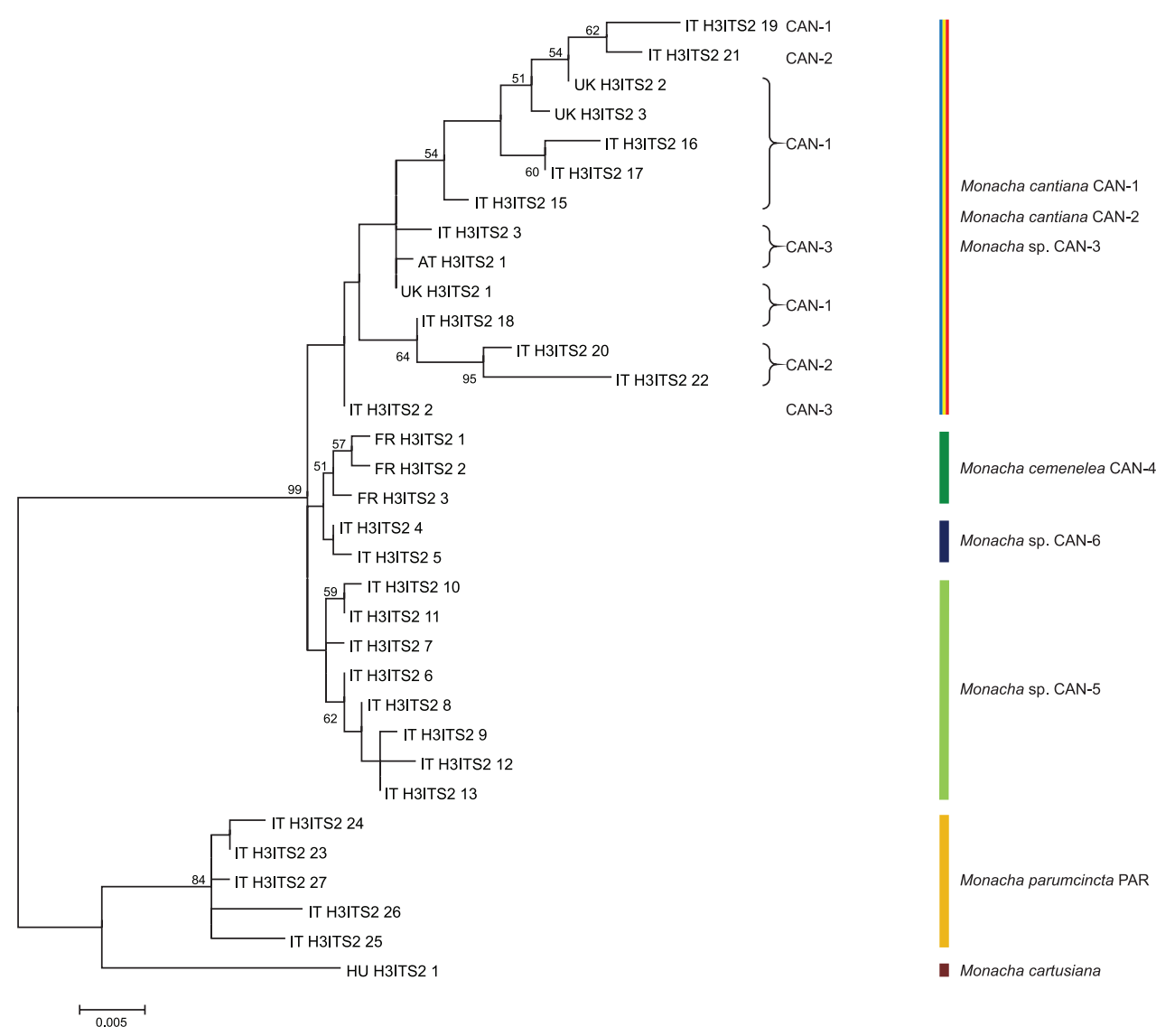

Figure 2. Maximum Likelihood (ML) tree of combined H3 and ITS2 common sequences of Monacha cantiana s.l. (see Table 4). Numbers next to the branches indicate bootstrap support above $50 \%$ calculated for 1000 replicates (Felsenstein 1985). The tree was rooted with M. cartusiana and M. parumcincta combined sequences obtained from GenBank (Table 4).

Bayesian phylogenetic tree of combined sequences of COI+16SrDNA+H3+ITS2 gene fragments (Fig. 3, Table 4) clustered the combined sequences in two separate clades (CAN-5 and CAN-6), which were also separate from all other clades recognised previously for $M$. cantiana (CAN-1, CAN-2, CAN-3), M. cemenelea (CAN-4) and $M$. parumcincta (PAR) populations (Pieńkowska et al. 2018).

Networks of COI (Fig. 4) and 16SrDNA (Fig. 5) confirmed separateness of clades CAN-5 and CAN-6 and all other previously recognised clades (CAN-1 to CAN-4, PAR; Pieńkowska et al. 2018).

K2P genetic distances between COI haplotypes are summarised in Table 5. The smallest distances are within haplotypes of particular clades $(0.2-2.2 \%$, slightly larger $1.0-4.2 \%$ within $M$. parumcincta). As shown previously (Pieńkowska et al. 2018), the K2P distances between CAN-1 and CAN-2, and between CAN-3 and CAN-4, were smaller (3.3-5.1\% and 5.1-6.2\%, respectively) than between other clades compared 


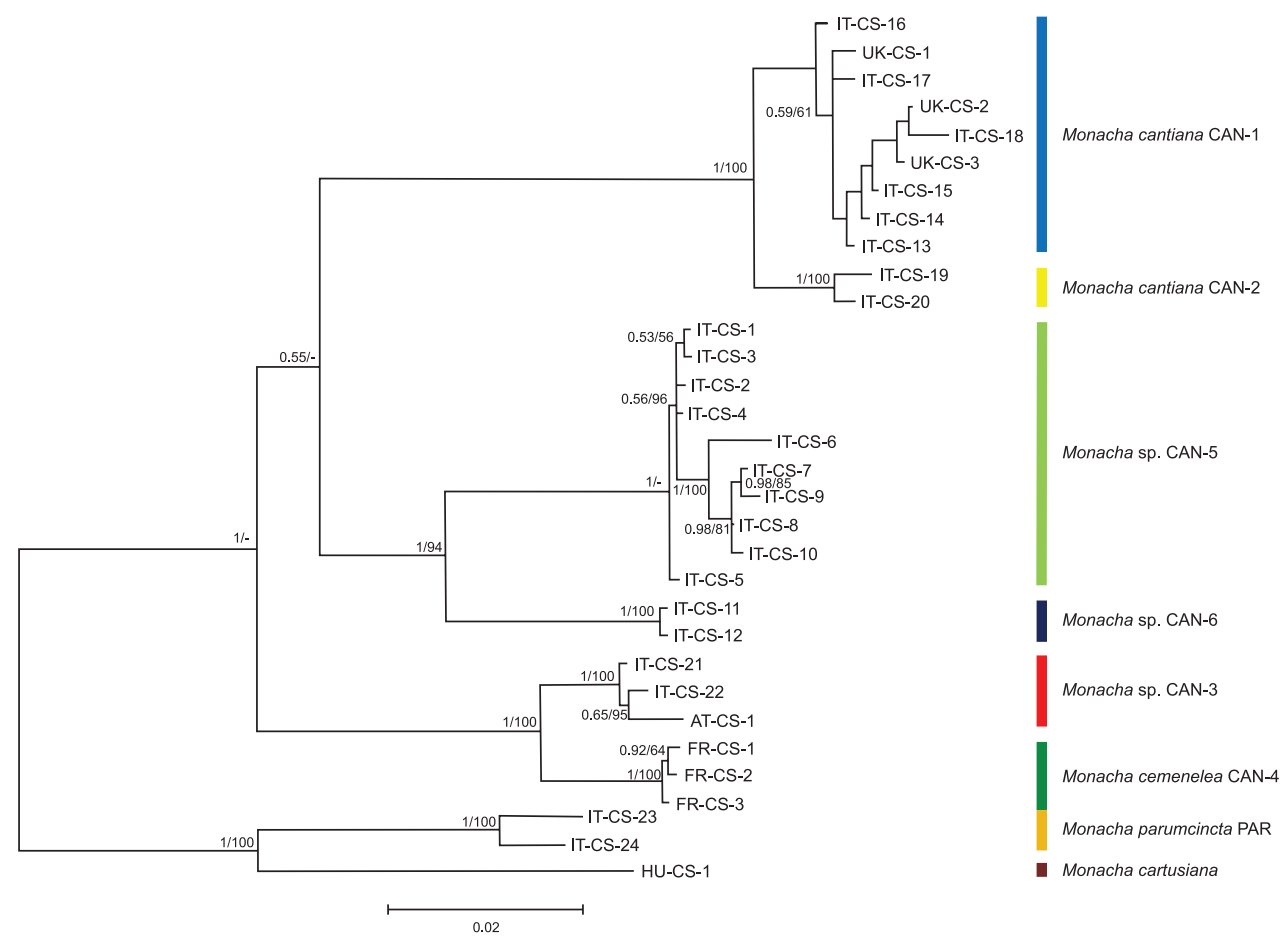

Figure 3. Bayesian 50\% majority-rule consensus tree of the combined data set of COI and 16SrDNA haplotypes, and $\mathrm{H} 3$ and ITS2 common sequences (see Table 4). Posterior probabilities (left) and bootstrap support above 50\% from ML analysis (right) are indicated next to the branches. Bootstrap analysis was run with 1000 replicates (Felsenstein 1985). The tree was rooted with M. cartusiana and M. parumcincta combined sequences obtained from GenBank (Table 4).

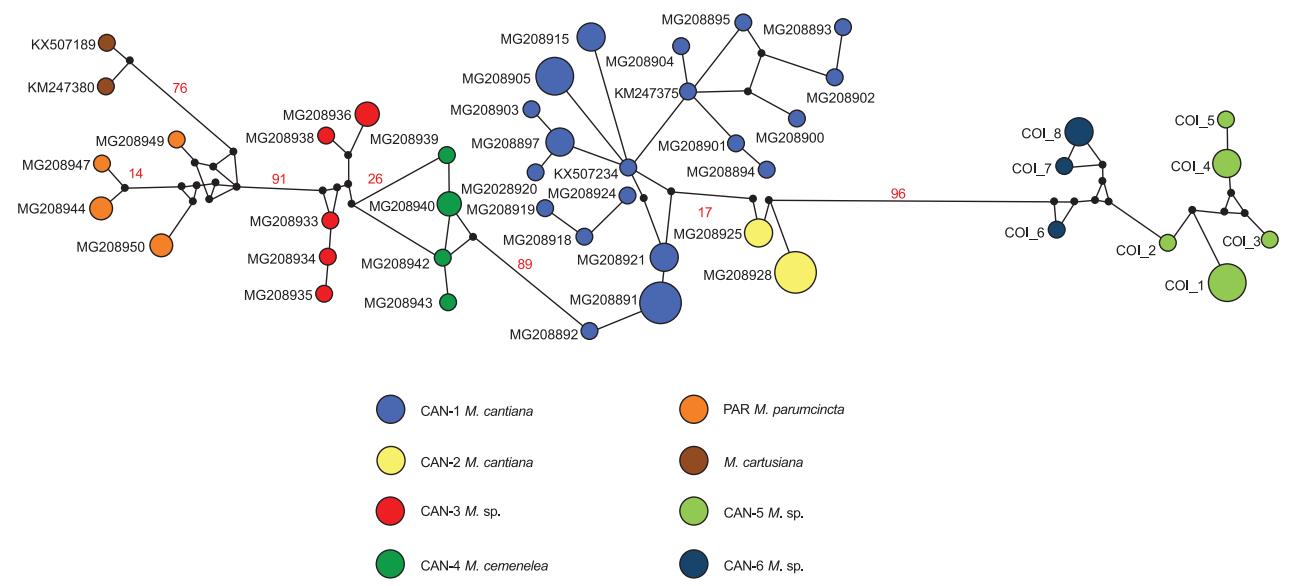

Figure 4. The median-joining haplotype network for COI haplotypes of Monacha cantiana s.l. The colours of the circles indicate Monacha species, and their size is proportional to haplotype frequencies. Small black circles are hypothetical missing intermediates. The numbers next to the branches indicate distance between taxa expressed in numbers of mutant positions. Only numbers above 10 are indicated. 


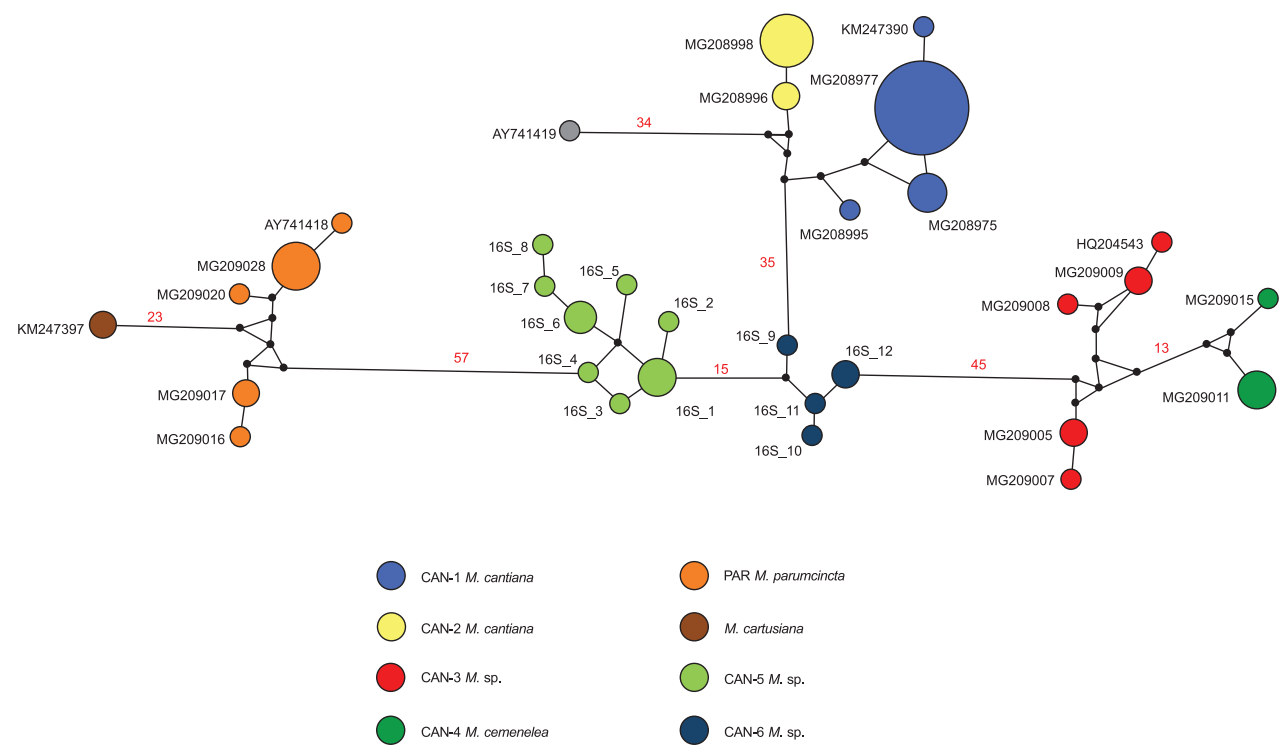

Figure 5. Haplotype network for 16SrDNA of Monacha cantiana s.l. Other explanations as in Figure 4.

in pairs (Table 5). The clades CAN-5 and CAN-6 differed considerably (12.4-14.3\%). The clade CAN-5 differed to a similar degree from CAN-3 and CAN-4 clades (13.315.4\%). Differences between these two clades (CAN-3 and CAN-4) and the clade CAN-6 were even larger (14.3-16.8\%). Both CAN-5 and CAN-6 were also separated by very large genetic distances from all other clades (16.5-21.3\%).

\section{Morphological study: shell}

The two new clades of M. cantiana s.l. (CAN-5, CAN-6: Figs 6-15) have a globosesubglobose shell, variable in size and usually whitish or pale yellowish, with slightly descending, roundish to oval aperture, very similar to those of the other lineages (CAN-1, CAN-2, CAN-3, CAN-4; see Pieńkowska et al. 2018: figs 8-15), but clearly distinguished by a larger, very open umbilicus.

M. cantiana s.l. (lineages CAN-1 to CAN-6) is always distinguished from M. parumcincta by its umbilicus (open in $M$. cantiana s.l.; closed in $M$. parumcincta). Some populations of $M$. parumcincta have variably evident whitish peripheral and subsutural bands (evident if the last whorl is reddish) and/or a less glossy (more opaque) shell surface.

RDA with lineage constraint on the shape and size matrix (Fig. 16) showed that RDA $1(44 \%, p<0.001)$ separated the groups CAN-1, CAN-2, CAN-3, CAN-4, CAN-5 and CAN-6 from PAR. The preliminary classic PCA revealed size as the first major source of morphological variation, since PC1 $(74 \%)$ was a positive combination of all variables. On the contrary, RDA $2(7 \%, p<0.01)$ separated CAN-1, CAN-2 and CAN-3 from CAN-4, CAN-5 and CAN-6 with PAR in intermediate position. In this regard, PC2 (11\%) accounted for a contrast between $\mathrm{LWmH}$ vs $\mathrm{LWaH}$ and $\mathrm{PWH}$ variables. 
Table 5. Ranges of K2P genetic distances for COI sequences analysed (mean values in parentheses).

\begin{tabular}{|c|c|}
\hline Comparison & COI (\%) \\
\hline Within $M$. cantiana $\mathrm{CAN}-1$ & $0.2-2.2(0.8)$ \\
\hline Within M. cantiana CAN-2 & $0.3(0.3)$ \\
\hline Within $M$. sp. CAN-3 & $0.2-1.9(1.2)$ \\
\hline Within M. cemenelea CAN-4 & $0.2-0.5(0.3)$ \\
\hline Within $M$. sp. CAN-5 & $0.2-1.7(1.3)$ \\
\hline Within $M$. sp. CAN-6 & $0.2-2.2(1.6)$ \\
\hline Within $M$. parumcincta & $1.0-4.2(3.0)$ \\
\hline Within $M$. cartusiana & 0.5 \\
\hline Between $M$. cantiana CAN-1 and $M$. cantiana CAN-2 & $3.3-5.1(3.9)$ \\
\hline Between $M$. cantiana CAN- 1 and $M$. sp. CAN-3 & $17.6-19.2(18.6)$ \\
\hline Between $M$. cantiana CAN- 1 and $M$. cemenelea CAN- 4 & $17.2-18.7(18.0)$ \\
\hline Between $M$. cantiana CAN-1 and $M$. sp. CAN-5 & $16.5-18.2(17.5)$ \\
\hline Between $M$. cantiana CAN-1 and $M$. sp. CAN-6 & $18.0-19.2(18.6)$ \\
\hline Between $M$. cantiana CAN-1 and $M$. parumcincta & $19.6-21.7(20.7)$ \\
\hline Between $M$. cantiana CAN-1 and M. cartusiana & $18.9-20.5(19.7)$ \\
\hline Between $M$. cantiana CAN-2 and $M$. sp. CAN-3 & $17.8-18.2(18.1)$ \\
\hline Between $M$. cantiana CAN-2 and M. cemenelea CAN-4 & $18.2-18.7(18.5)$ \\
\hline Between $M$. cantiana CAN-2 and $M$. sp. CAN-5 & $17.6-18.2(17.9)$ \\
\hline Between $M$. cantiana CAN-2 and $M$. sp. CAN-6 & $18.3-19.0(18.5)$ \\
\hline Between $M$. cantiana CAN-2 and M. parumcincta & $19.8-20.7(20.2)$ \\
\hline Between $M$. cantiana CAN-2 and M. cartusiana & 21.4 \\
\hline Between $M$. sp. CAN-3 and M. cemenelea CAN-4 & $5.1-6.2(5.6)$ \\
\hline Between $M$. sp. CAN-3 and $M$. sp. CAN-5 & $13.3-14.4(13.8)$ \\
\hline Between $M$. sp. CAN-3 and M. sp. CAN-6 & $14.3-16.7(15.7)$ \\
\hline Between $M$. sp. CAN-3 and M. parumcincta & $18.4-21.4(19.6)$ \\
\hline Between $M$. sp. CAN-3 and M. cartusiana & $18.4-20.0(19.1)$ \\
\hline Between $M$. cemenelea CAN-4 and $M$. sp. CAN-5 & $14.8-15.4(15.1)$ \\
\hline Between $M$. cemenelea CAN-4 and $M$. sp. CAN-6 & $16.4-16.8(16.6)$ \\
\hline Between $M$. cemenelea CAN-4 and $M$. parumcincta & $19.5-20.5(19.9)$ \\
\hline Between $M$. cemenelea CAN-4 and M. cartusiana & $18.9-19.3(19.0)$ \\
\hline Between $M$. sp. CAN-5 and M. sp. CAN-6 & $12.4-14.3(13.6)$ \\
\hline Between $M$. sp. CAN-5 and M. parumcincta & $17.3-20.2(18.5)$ \\
\hline Between $M$. sp. CAN-5 and M. cartusiana & $20.6-21.3(21.1)$ \\
\hline Between $M$. sp. CAN-6 and M. parumcincta & $17.6-19.1(18.2)$ \\
\hline Between M. sp. CAN-6 and M. cartusiana & $17.3-17.8(17.5)$ \\
\hline
\end{tabular}

RDA on the shape (Z) matrix (Fig. 17) showed no separation of lineages, confirming that size is a major source of morphological variation. Shape-related PCA indicated that LWfW and LWmW vs SH, LWaH and PWH were the two principal shape determinants on PC1 and AD vs UD on PC2.

Box plots (Fig. 18) proved the poor discriminating value of shell characters in distinguishing lineage pairs. The best discriminant character was UD that distinguished 13 clade pairs according to Tukey's honestly significant difference test, followed by LWmH and LWmW that distinguished seven clade pairs each. The most recognizable pairs were CAN-1 vs PAR, CAN-3 vs PAR, CAN-6 vs PAR, CAN-2 vs PAR and CAN-5 vs PAR (12, 11, 10, 8 and 7 significant characters, respectively). Five significant shell characters distinguished CAN-3 vs CAN-4, four CAN-4 vs CAN-6, two CAN-1 vs CAN-4, CAN-1 vs CAN-5 or CAN-3 vs CAN-5 and only one CAN-1 vs 


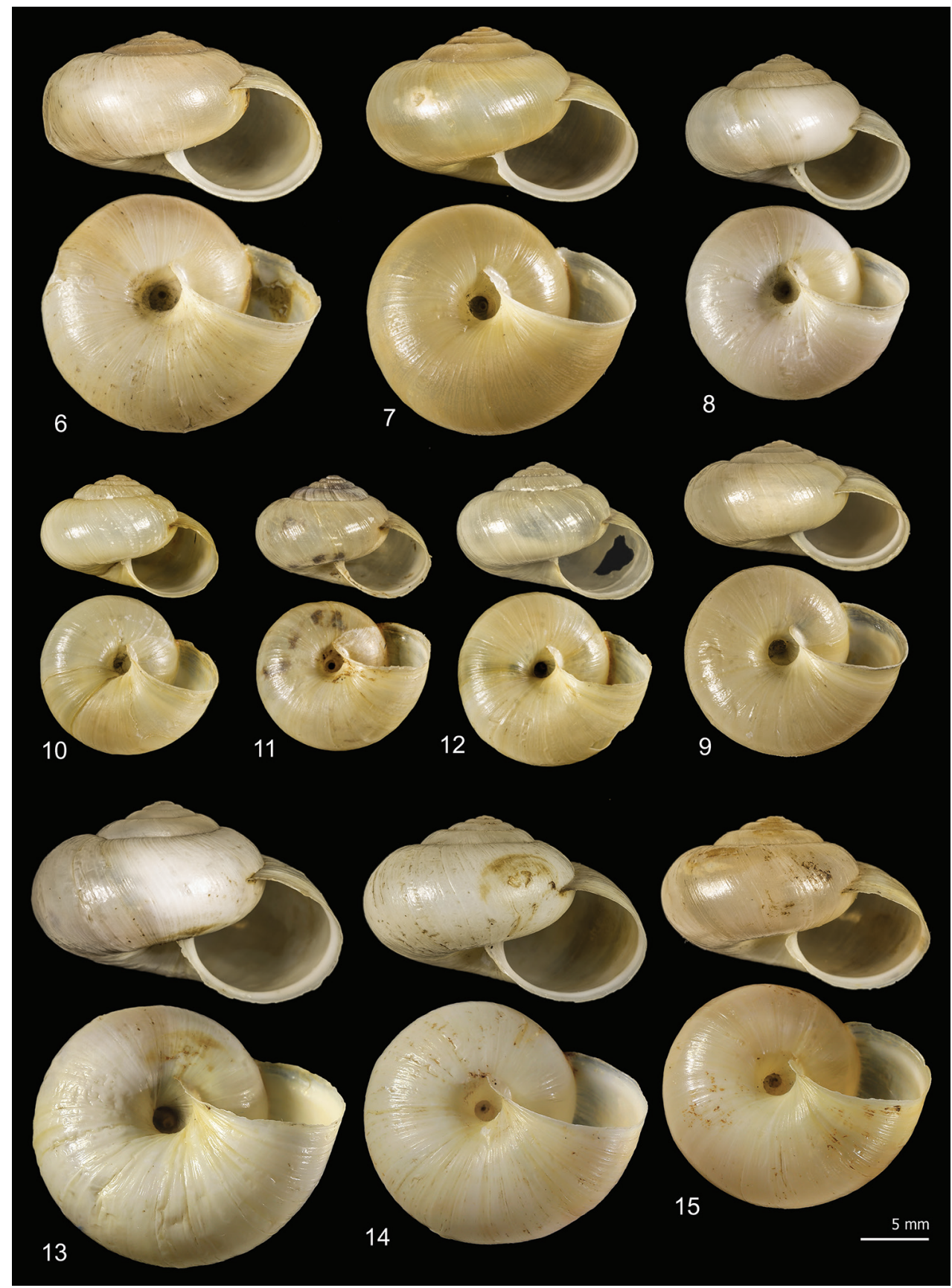

Figures 6-15. Shell variability in Monacha cantiana s.l. CAN-5 from Piastra (FGC 41563) (6, 7), Foce di Pianza (FGC 41565) $(\mathbf{8 , 9}$ ) and Campo Cecina (FGC 41564) (I0-I 2); CAN-6 from Campagrina (FGC 40322) (I3-I5). 


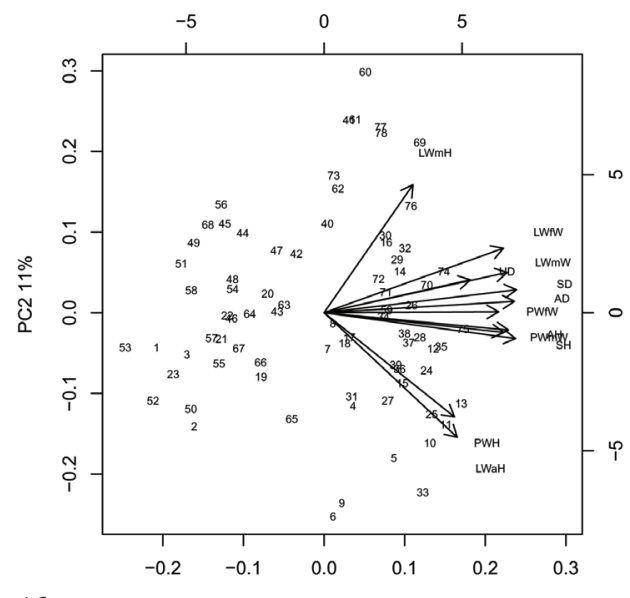

16
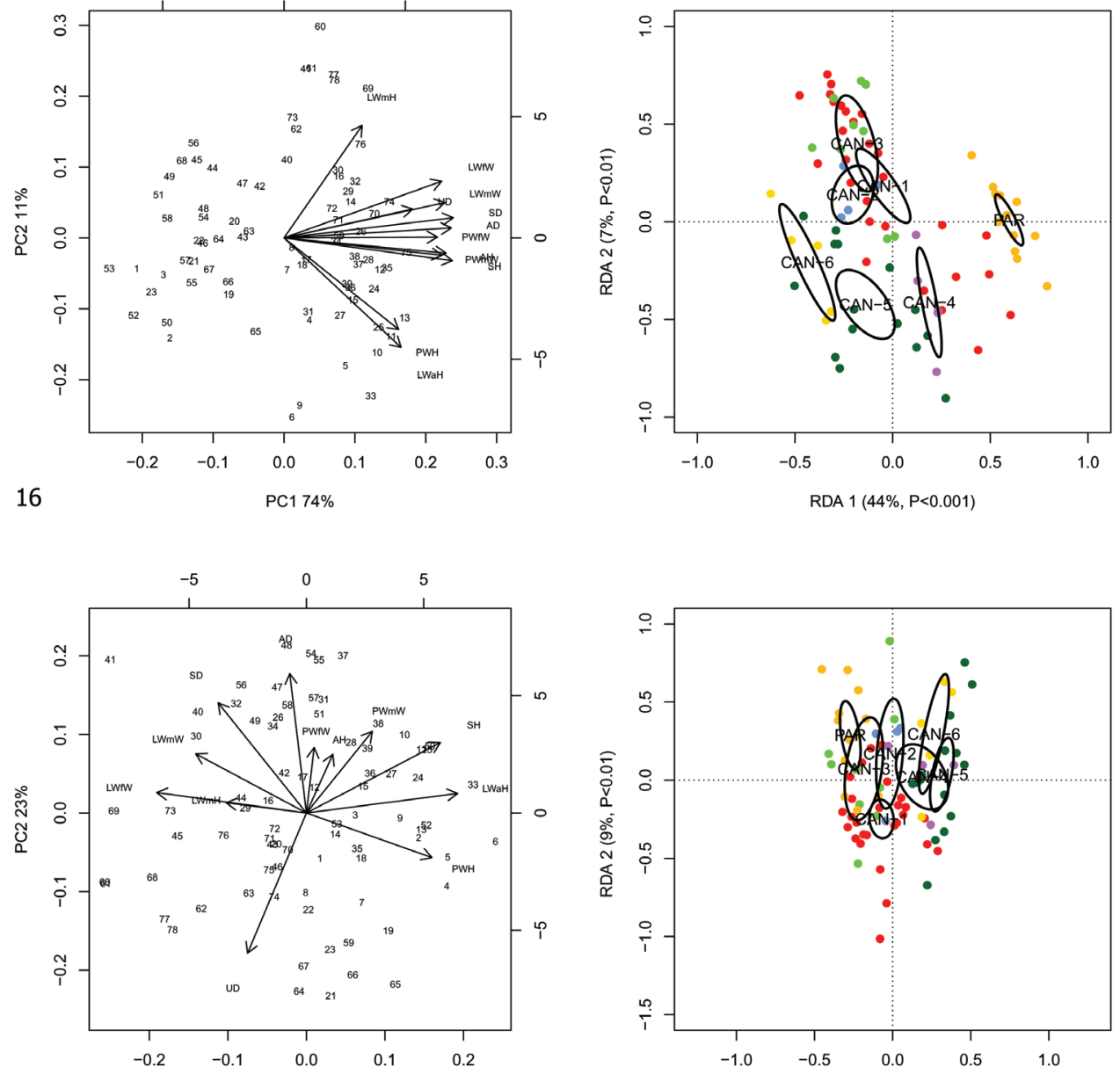

17

PC1 35\%

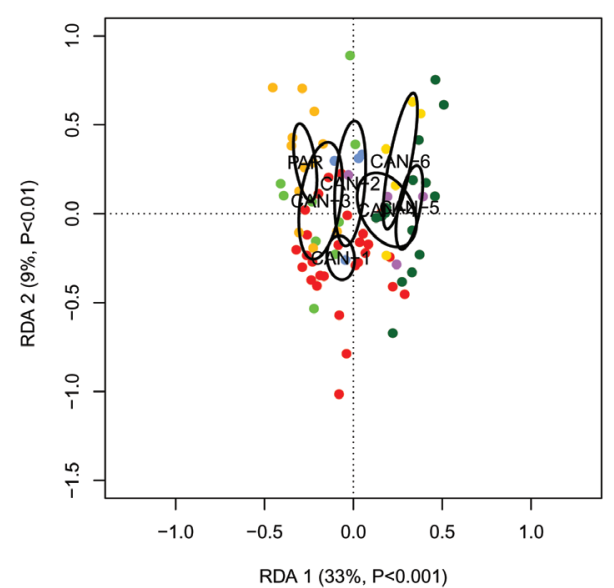

Figures 16, 17. Principal component analysis (PCA) and Redundancy analysis (RDA) with lineage constraint applied to the original shell matrix (I6) and Z-matrix (shape-related) (I7).

CAN-6, CAN-2 vs CAN-6, CAN-3 vs CAN-6, CAN-4 vs CAN-5 or CAN-4 vs PAR. No significant character distinguished CAN-1 vs CAN-2, CAN-1 vs CAN-3, CAN-2 vs CAN-3, CAN-2 vs CAN-4, CAN-2 vs CAN-5 or CAN-5 vs CAN-6 (Table 6).

\section{Morphological study: anatomy}

The bodies (generally pinkish or yellowish white) and mantle (with sparse brown or blackish spots near the mantle border or on the lung surface, a larger one close to the pneumostomal opening) of CAN-5 and CAN-6 are very similar to those of the other lineages of $M$. cantiana s.l. and M. parumcincta studied so far (Pieńkowska et al. 2018). The 

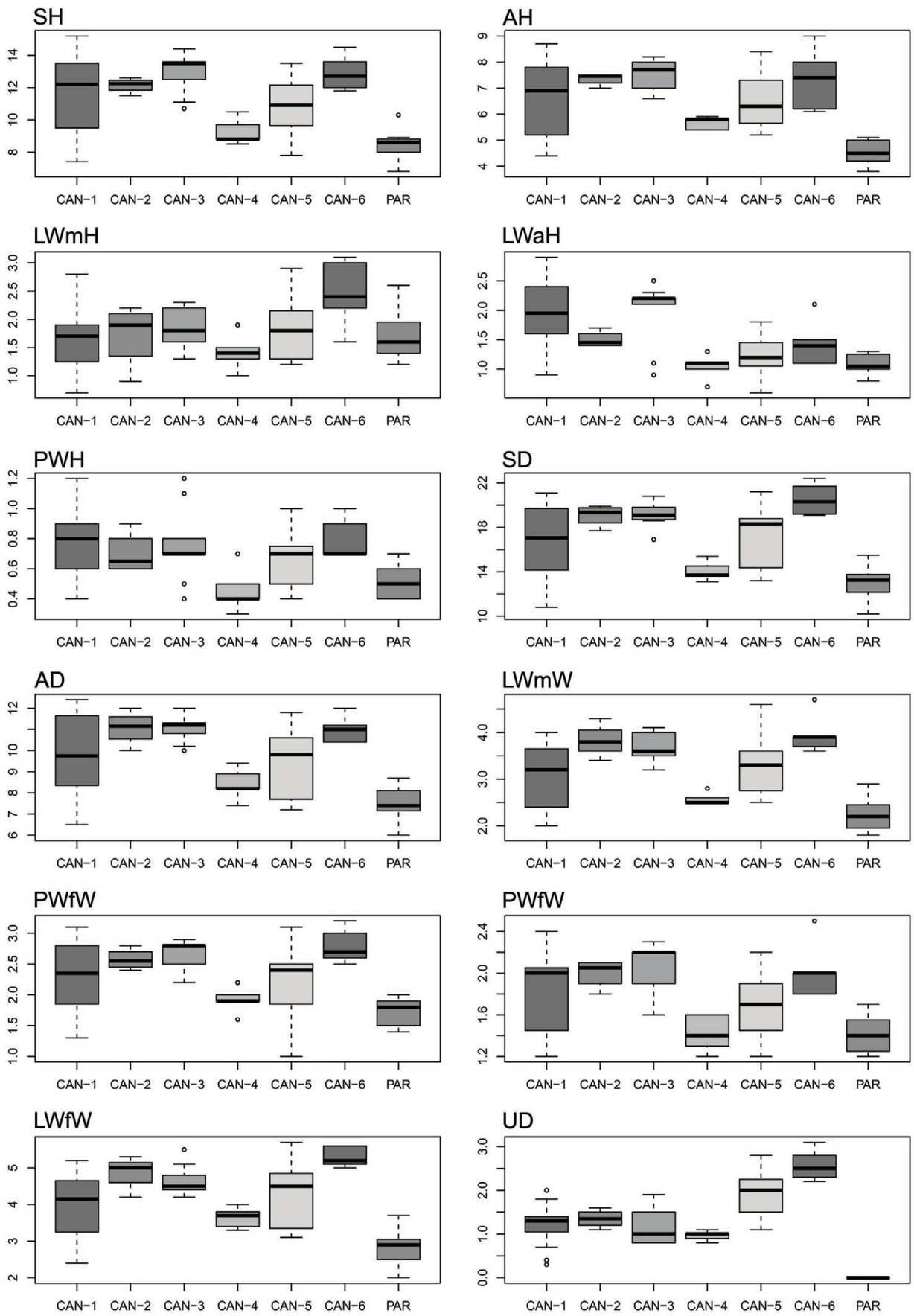

Figure 18. Box plots for shell characters of the seven Monacha clades investigated. The lower and upper limits of the rectangular boxes indicate the $25^{\text {th }}$ to $75^{\text {th }}$ percentile range, and the horizontal line within the boxes is the median $\left(50^{\text {th }}\right.$ percentile). 
Table 6. Results of Tukey's honestly significant difference (HSD) test for shell and genitalia characters (in bold Tukey's post-hoc $\mathrm{p} \leq 0.01$ ).

\begin{tabular}{|c|c|c|c|c|c|c|}
\hline Pairs & SH & AH & LWmH & LWaH & PWH & SD \\
\hline CAN-1 vs CAN-2 & 0.99624 & 0.80619 & 0.13492 & 0.64537 & 0.99057 & 0.63122 \\
\hline CAN-1 vs CAN-3 & 0.52140 & 0.28168 & 0.06284 & 1.00000 & 0.99999 & 0.22745 \\
\hline CAN-1 vs CAN-4 & 0.08096 & 0.59307 & 0.54497 & 0.00097 & 0.00582 & 0.34307 \\
\hline CAN-1 vs CAN-5 & 0.81752 & 0.99959 & 0.86439 & 0.00006 & 0.44707 & 0.99988 \\
\hline CAN-1 vs CAN-6 & 0.77627 & 0.80465 & 0.02347 & 0.29268 & 0.99992 & 0.08726 \\
\hline CAN-1 vs PAR & 0.00001 & 0.00000 & 0.00009 & 0.00001 & 0.00125 & 0.00032 \\
\hline CAN-2 vs CAN-3 & 0.99544 & 0.99999 & 0.99929 & 0.77166 & 0.99881 & 1.00000 \\
\hline CAN-2 vs CAN-4 & 0.15929 & 0.22915 & 0.01822 & 0.55297 & 0.33334 & 0.07297 \\
\hline CAN-2 vs CAN-5 & 0.82169 & 0.71176 & 0.57227 & 0.84890 & 0.99950 & 0.79654 \\
\hline CAN-2 vs CAN-6 & 0.99776 & 1.00000 & 0.99993 & 0.99994 & 0.98407 & 0.99242 \\
\hline CAN-2 vs PAR & 0.00365 & 0.00008 & 0.00002 & 0.51420 & 0.51214 & 0.00095 \\
\hline CAN-3 vs CAN-4 & 0.00643 & 0.04670 & 0.01004 & 0.00675 & 0.03910 & 0.01412 \\
\hline CAN-3 vs CAN-5 & 0.10929 & 0.23103 & 0.60853 & 0.00526 & 0.85885 & 0.48747 \\
\hline CAN-3 vs CAN-6 & 1.00000 & 0.99988 & 0.97726 & 0.47647 & 0.99950 & 0.98207 \\
\hline CAN-3 vs PAR & 0.00000 & 0.00000 & 0.00000 & 0.00068 & 0.04033 & 0.00001 \\
\hline CAN-4 vs CAN-5 & 0.53531 & 0.81117 & 0.17929 & 0.96835 & 0.24318 & 0.30059 \\
\hline CAN-4 vs CAN-6 & 0.02495 & 0.21289 & 0.00350 & 0.68422 & 0.03827 & 0.00540 \\
\hline CAN-4 vs PAR & 0.94161 & 0.19901 & 0.70423 & 0.99998 & 0.99243 & 0.94050 \\
\hline CAN-5 vs CAN-6 & 0.30662 & 0.70539 & 0.24510 & 0.94331 & 0.73973 & 0.19886 \\
\hline CAN-5 vs PAR & 0.00429 & 0.00004 & 0.00001 & 0.97460 & 0.33336 & 0.00072 \\
\hline CAN-6 vs PAR & 0.00009 & 0.00003 & 0.00000 & 0.65314 & 0.05065 & 0.00001 \\
\hline Pairs & $\mathrm{AD}$ & LWmW & PWmW & PWfW & LWfW & UD \\
\hline CAN-1 vs CAN-2 & 0.69737 & 0.13492 & 0.93036 & 0.87269 & 0.31096 & 0.96096 \\
\hline CAN-1 vs CAN-3 & 0.31086 & 0.06284 & 0.60648 & 0.41696 & 0.21613 & 0.99999 \\
\hline CAN-1 vs CAN-4 & 0.50802 & 0.54497 & 0.09498 & 0.68052 & 0.97680 & 0.88793 \\
\hline CAN-1 vs CAN-5 & 0.96922 & 0.86439 & 0.80483 & 0.97841 & 0.92956 & 0.00001 \\
\hline CAN-1 vs CAN-6 & 0.64832 & 0.02347 & 0.86310 & 0.28589 & 0.01739 & 0.00000 \\
\hline CAN-1 vs PAR & 0.00015 & 0.00009 & 0.00253 & 0.00752 & 0.00003 & 0.00000 \\
\hline CAN-2 vs CAN-3 & 1.00000 & 0.99929 & 1.00000 & 1.00000 & 0.99951 & 0.95368 \\
\hline CAN-2 vs CAN-4 & 0.13909 & 0.01822 & 0.07501 & 0.33305 & 0.22490 & 0.65706 \\
\hline CAN-2 vs CAN-5 & 0.41336 & 0.57227 & 0.53801 & 0.63842 & 0.76317 & 0.27349 \\
\hline CAN-2 vs CAN-6 & 1.00000 & 0.99993 & 1.00000 & 0.99559 & 0.99073 & 0.00493 \\
\hline CAN-2 vs PAR & 0.00086 & 0.00002 & 0.01749 & 0.02031 & 0.00004 & 0.00000 \\
\hline CAN-3 vs CAN-4 & 0.03838 & 0.01004 & 0.01014 & 0.09468 & 0.21544 & 0.97116 \\
\hline CAN-3 vs CAN- 5 & 0.11621 & 0.60853 & 0.13645 & 0.18479 & 0.82554 & 0.00061 \\
\hline CAN-3 vs CAN-6 & 1.00000 & 0.97726 & 1.00000 & 0.99741 & 0.83628 & 0.00001 \\
\hline CAN-3 vs PAR & 0.00001 & 0.00000 & 0.00029 & 0.00030 & 0.00000 & 0.00000 \\
\hline CAN-4 vs CAN-5 & 0.89567 & 0.17929 & 0.58669 & 0.95667 & 0.75219 & 0.00034 \\
\hline CAN-4 vs CAN-6 & 0.11242 & 0.00350 & 0.04140 & 0.06153 & 0.02534 & 0.00000 \\
\hline CAN-4 vs PAR & 0.78586 & 0.70423 & 1.00000 & 0.96612 & 0.13925 & 0.00000 \\
\hline CAN-5 vs CAN-6 & 0.35200 & 0.24510 & 0.38979 & 0.13051 & 0.16182 & 0.17535 \\
\hline CAN-5 vs PAR & 0.01180 & 0.00001 & 0.19674 & 0.14546 & 0.00001 & 0.00000 \\
\hline CAN-6 vs PAR & 0.00030 & 0.00000 & 0.00588 & 0.00062 & 0.00000 & 0.00000 \\
\hline Pairs & DBC & $\mathrm{V}$ & F & $\mathbf{E}$ & $\mathbf{P}$ & VA \\
\hline CAN-1 vs CAN-2 & 0.07018 & 0.99978 & 0.78435 & 0.11949 & 0.17040 & 0.00083 \\
\hline CAN-1 vs CAN-3 & 0.95915 & 0.99932 & 0.98006 & 0.74183 & 0.08763 & 0.23114 \\
\hline CAN-1 vs CAN-4 & 0.99996 & 0.63222 & 0.22100 & 0.81959 & 0.76747 & 0.89555 \\
\hline CAN-1 vs CAN-5 & 0.94079 & 0.99983 & 0.00000 & 0.23792 & 0.98466 & 0.98588 \\
\hline CAN-1 vs CAN-6 & 0.21936 & 0.02524 & 0.00000 & 0.84359 & 1.00000 & 0.13261 \\
\hline CAN-1 vs PAR & 0.95468 & 0.00603 & 0.01845 & 0.00032 & 0.98841 & 0.00000 \\
\hline CAN-2 vs CAN-3 & 0.59703 & 0.99388 & 0.99743 & 0.91922 & 1.00000 & 0.48744 \\
\hline CAN-2 vs CAN-4 & 0.22526 & 0.62669 & 0.04688 & 0.04004 & 0.04443 & 0.29982 \\
\hline CAN-2 vs CAN-5 & 0.01390 & 0.99642 & 0.00000 & 0.98147 & 0.55615 & 0.00027 \\
\hline CAN-2 vs CAN-6 & 1.00000 & 0.04898 & 0.00000 & 0.97601 & 0.52105 & 0.95169 \\
\hline CAN-2 vs PAR & 0.02181 & 0.16528 & 0.84806 & 0.00000 & 0.08682 & 0.00000 \\
\hline CAN-3 vs CAN-4 & 0.96675 & 0.90393 & 0.11396 & 0.27618 & 0.02653 & 0.99623 \\
\hline CAN-3 vs CAN-5 & 0.60068 & 1.00000 & 0.00000 & 0.99937 & 0.42618 & 0.08653 \\
\hline CAN-3 vs CAN-6 & 0.78328 & 0.14420 & 0.00000 & 1.00000 & 0.43860 & 0.99411 \\
\hline CAN-3 vs PAR & 0.64853 & 0.01508 & 0.39875 & 0.00006 & 0.04538 & 0.00000 \\
\hline CAN-4 vs CAN-5 & 0.99962 & 0.81255 & 0.00036 & 0.08838 & 0.48386 & 0.65711 \\
\hline CAN-4 vs CAN-6 & 0.37610 & 0.86820 & 0.00508 & 0.37200 & 0.91204 & 0.91815 \\
\hline CAN-4 vs PAR & 0.99956 & 0.00208 & 0.00054 & 0.48361 & 0.98179 & 0.00000 \\
\hline CAN-5 vs CAN-6 & 0.06177 & 0.06806 & 1.00000 & 0.99998 & 0.99871 & 0.05266 \\
\hline CAN-5 vs PAR & 1.00000 & 0.00588 & 0.00000 & 0.00000 & 0.82000 & 0.00000 \\
\hline CAN-6 vs PAR & 0.07869 & 0.00001 & 0.00000 & 0.00088 & 0.99850 & 0.00000 \\
\hline
\end{tabular}




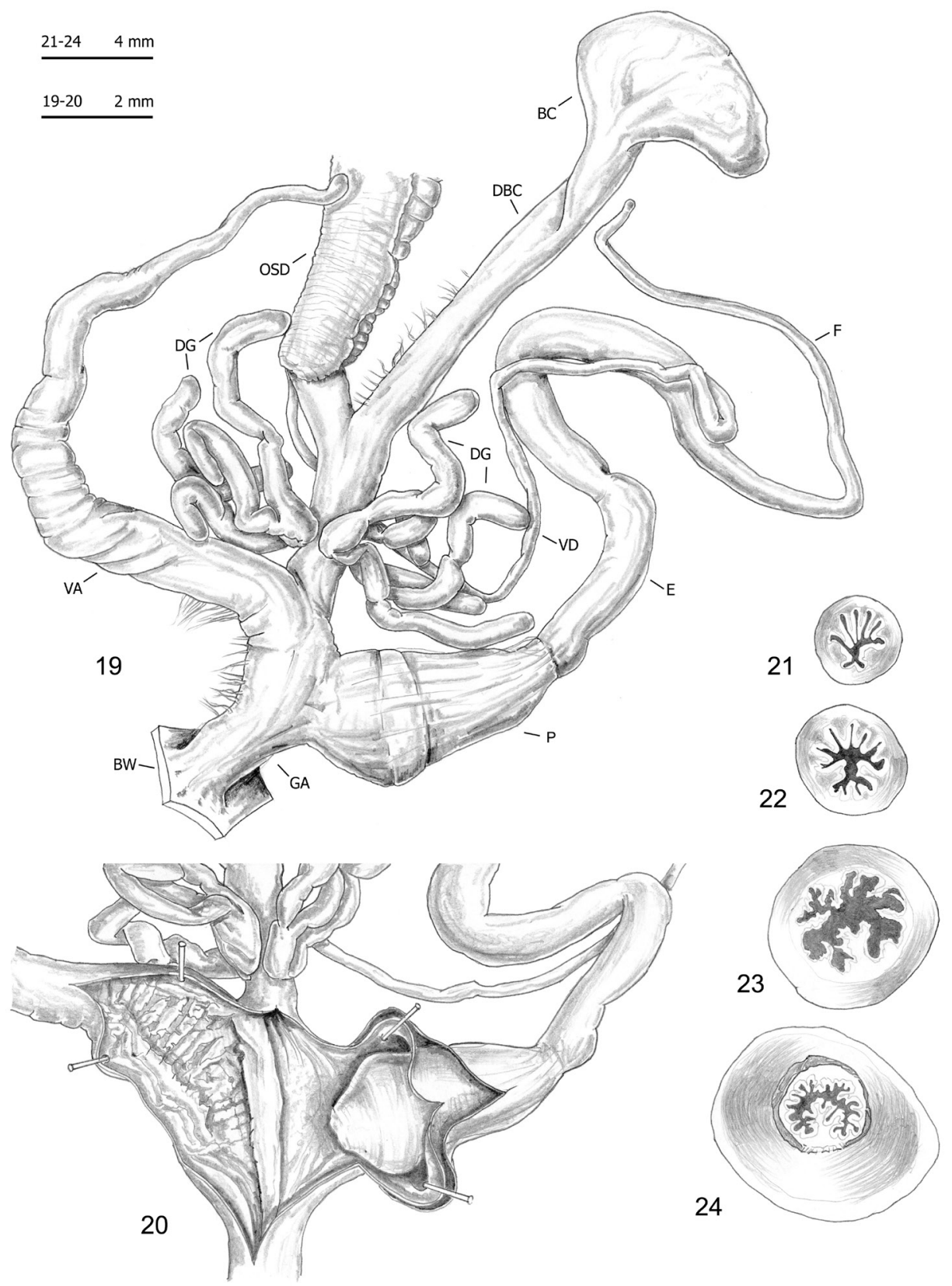

Figures 19-24. Genitalia (proximal parts excluded) (19), internal structure of distal genitalia (20), transverse sections of medial epiphallus $(\mathbf{2} \mathbf{1}, \mathbf{2 2})$ and basal and apical penial papilla $(\mathbf{2 3}, \mathbf{2 4})$ of Monacha cantiana s.l. CAN-5 from Piastra (FGC 41563). 

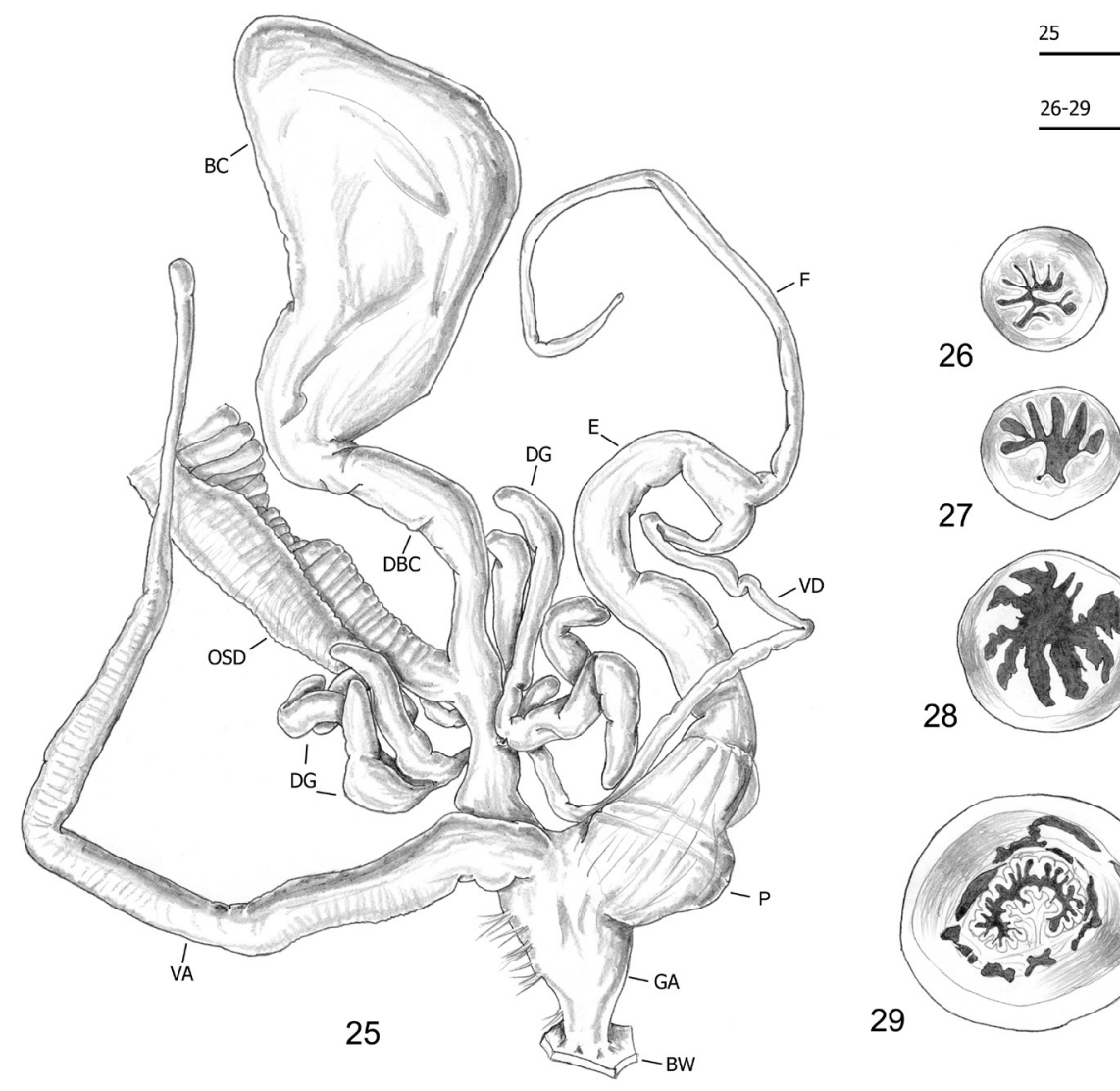

27

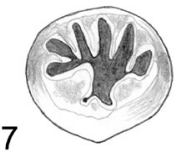

28

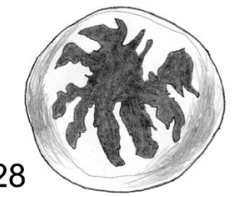

29

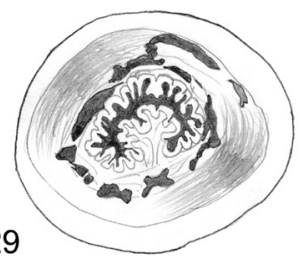

Figures 25-29. Genitalia (proximal parts excluded) (25), internal structure of distal genitalia (26), transverse sections of medial epiphallus $(\mathbf{2 7})$ and basal and apical penial papilla $(\mathbf{2 8}, \mathbf{2 9})$ of Monacha cantiana s.l. CAN-5 from Foce di Pianza (FGC 41565).

same is true of the distal genitalia (CAN-5: Figs 19-34; CAN-6: Figs 35-41), which as in the other lineages, have vaginal appendix (or "appendicula") rather long, always with thin walled terminal portion and with variably evident basal sac; vaginal-atrial pilaster variably evident; epiphallus section with five to six small pleats on one side, two large pleats on the opposite side and, between them, a very small pleat; penial papilla (or glans) section with central canal wide, thin walled, internally irregularly jagged and with a sort of solid pilaster on one side; central canal connected to external wall of penial papilla by many muscular/connective strings as in the other lineages (Pienkowska et al. 2018).

M. cantiana s.l. (lineages CAN-1 to CAN-6) is always distinguished from $M$. parumcincta by its vaginal appendix (rather long with thin-walled terminal portion and variably evident basal sac in $M$. cantiana; short, only occasionally with very short terminal portion and always without basal sac in $M$. parumcincta); vaginal-atrial pilaster (present and variably evident in M. cantiana s.l.; absent in M. parumcincta); penial papilla (central canal connected to external wall by many muscular/connective strings, 


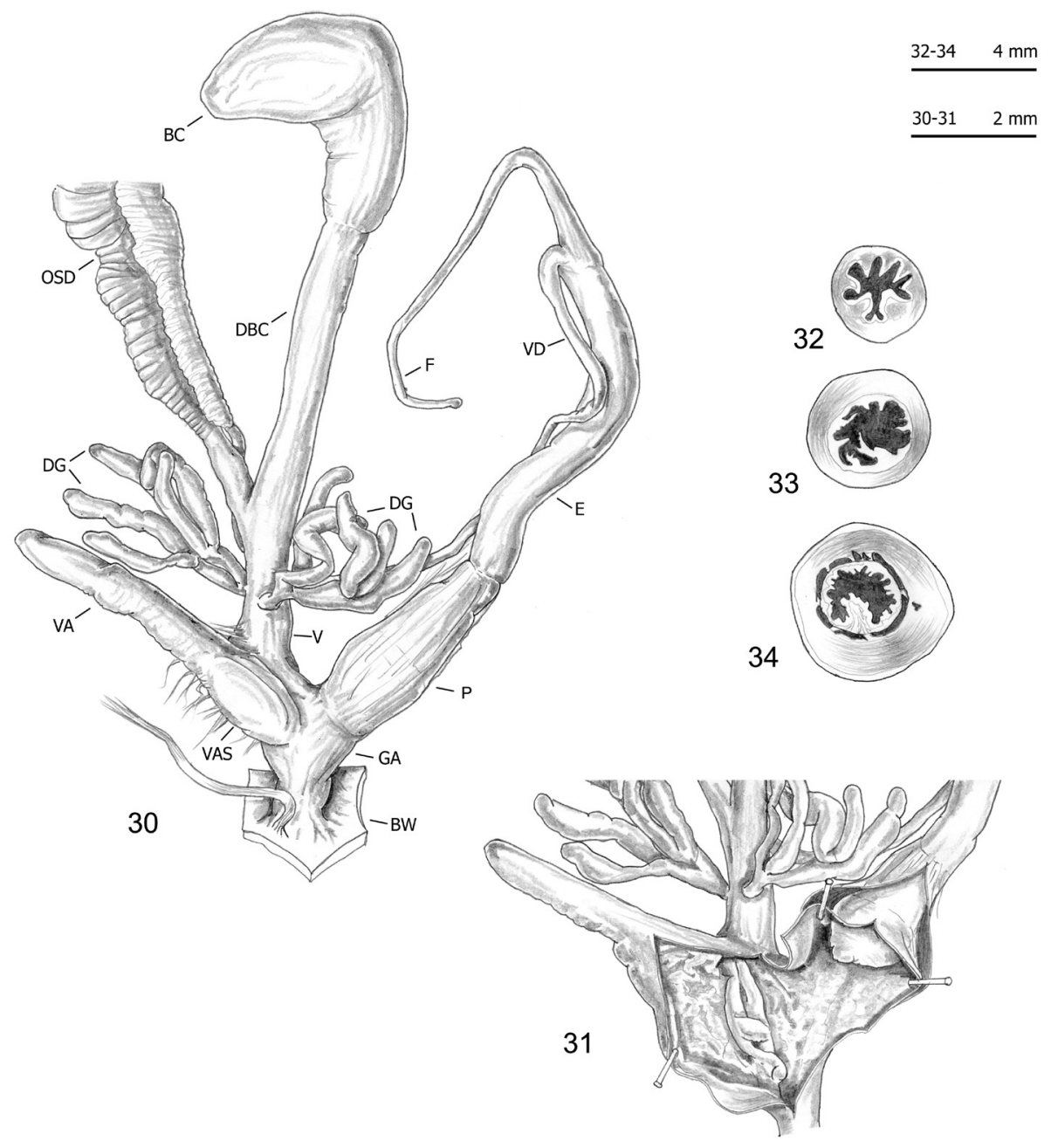

Figures 30-34. Genitalia (proximal parts excluded) (30), transverse sections of medial epiphallus $(\mathbf{3} \mathbf{1}, \mathbf{3 2})$ and basal and apical penial papilla $(\mathbf{3 3}, \mathbf{3 4})$ of Monacha cantiana s.l. CAN-5 Campo Cecina (FGC 41564).

internally jagged and with a sort of solid pilaster on one side in M. cantiana s.l.; central canal not connected to external wall, internally smooth or slightly jagged and almost completely filled by large invagination in $M$. parumcincta).

RDA with lineage constraint on the shape and size matrix (Fig. 42) showed that RDA $1(36 \%, p<0.001)$ separated the M. cantiana s.l. (CAN-1, CAN-2, CAN-3, CAN-4, CAN-5 and CAN-6) from PAR. The preliminary classic PCA revealed size as the first major source of morphological variation, since PC1 (54\%) was a positive combination of all variables. On the contrary, RDA $2(12 \%, p<0.001)$ separated the group CAN-1, CAN-2, CAN-3, CAN-4 and PAR from the group CAN-5 and CAN6. In that regard, PC2 (17\%) accounted for a contrast between $\mathrm{P}$ and $\mathrm{DBC}$ vs F. 


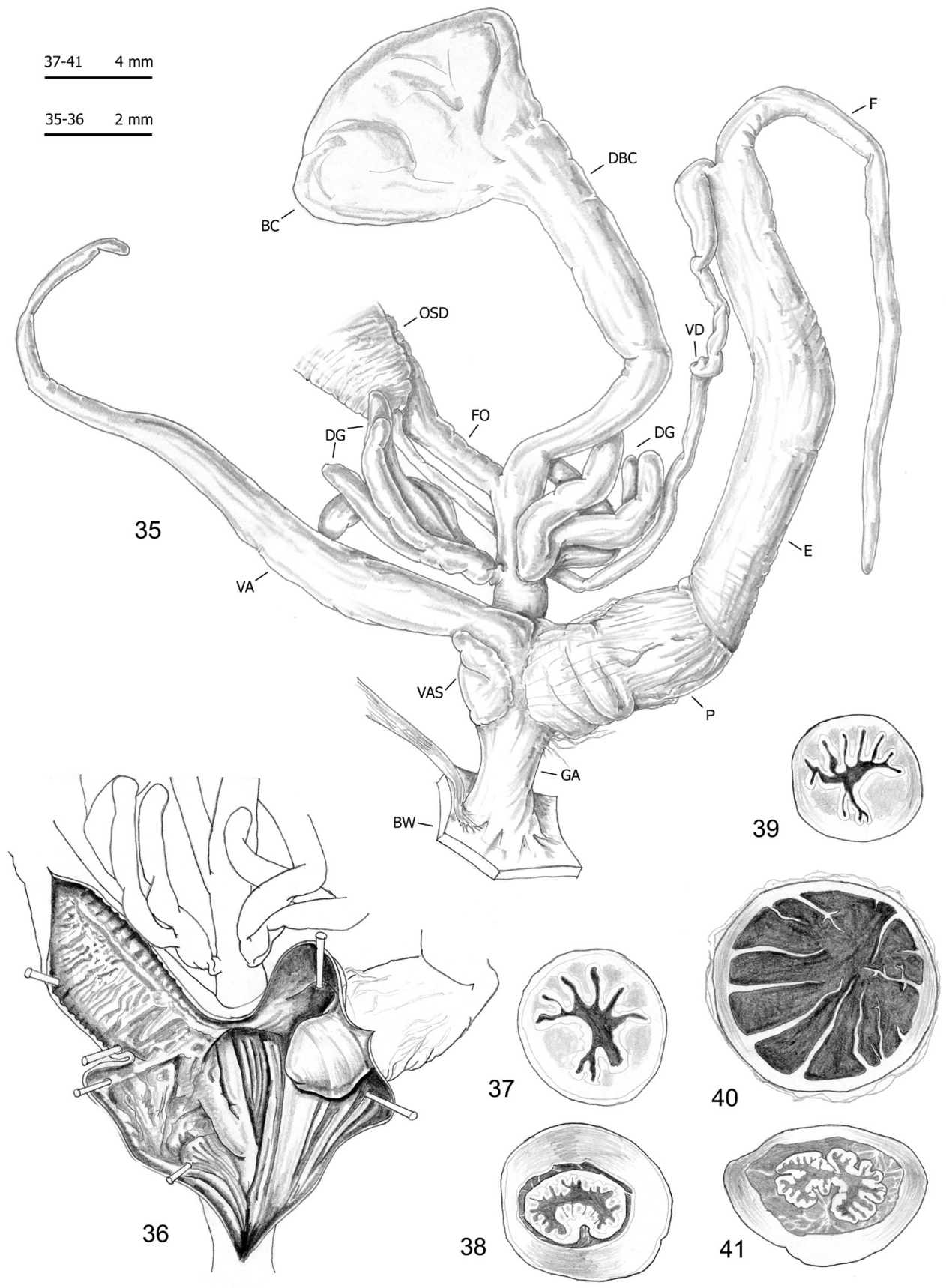

Figures 35-4I. Genitalia (proximal parts excluded) (35), internal structure of distal genitalia (36) and transverse sections of medial epiphallus $(\mathbf{3 7}, \mathbf{3 9})$, basal and apical penial papilla $(\mathbf{3 8}, \mathbf{4 0}, \mathbf{4 I})$ of Monacha cantiana s.l. CAN-6 from Campagrina (FGC 40322). 

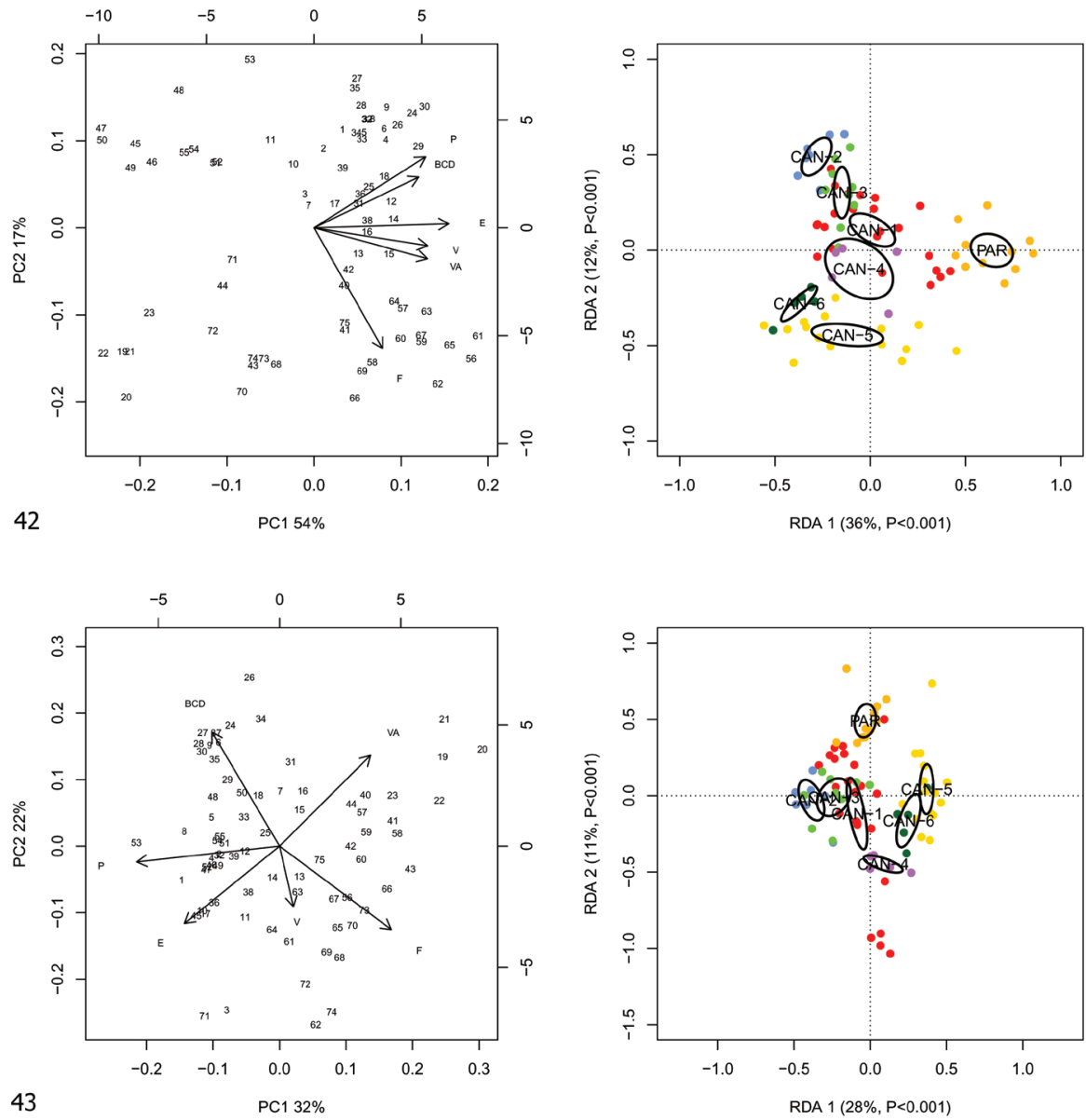

Figures 42, 43. Principal component analysis (PCA) and Redundancy analysis (RDA) with lineage applied to the original genitalia matrix (42) and Z-matrix (shape-related) (43).

RDA with species constraint on the shape $(Z)$ matrix (Fig. 43) showed that RDA $1(28 \%, p<0.001)$ separated the group CAN-1, CAN-2 and CAN-3 from the group CAN-5 and CAN-6 with PAR and CAN-4 in intermediate position and that RDA 2 $(11 \%, p<0.001)$ separated PAR from CAN-4 with the large group CAN-1, CAN-2, CAN-3, CAN-5 and CAN-6 in intermediate position. Shape-related PCA indicated that $\mathrm{P}, \mathrm{E}$ and $\mathrm{DBC}$ vs $\mathrm{VA}$ and $\mathrm{F}$ were the two principal shape determinants on PC1 and $\mathrm{DBC}$ and $\mathrm{VA}$ vs $\mathrm{E}, \mathrm{V}$ and $\mathrm{F}$ on PC2. In the latter case, removing the size effect altered the overall relationship patterns.

Box plots (Fig. 44) for anatomical characters showed that $\mathrm{F}$ and VA have the best discriminating value (they distinguished 11 and 8 clade pairs, respectively, according to Tukey's honestly significant difference test), followed by $\mathrm{E}$ and V (five and four 

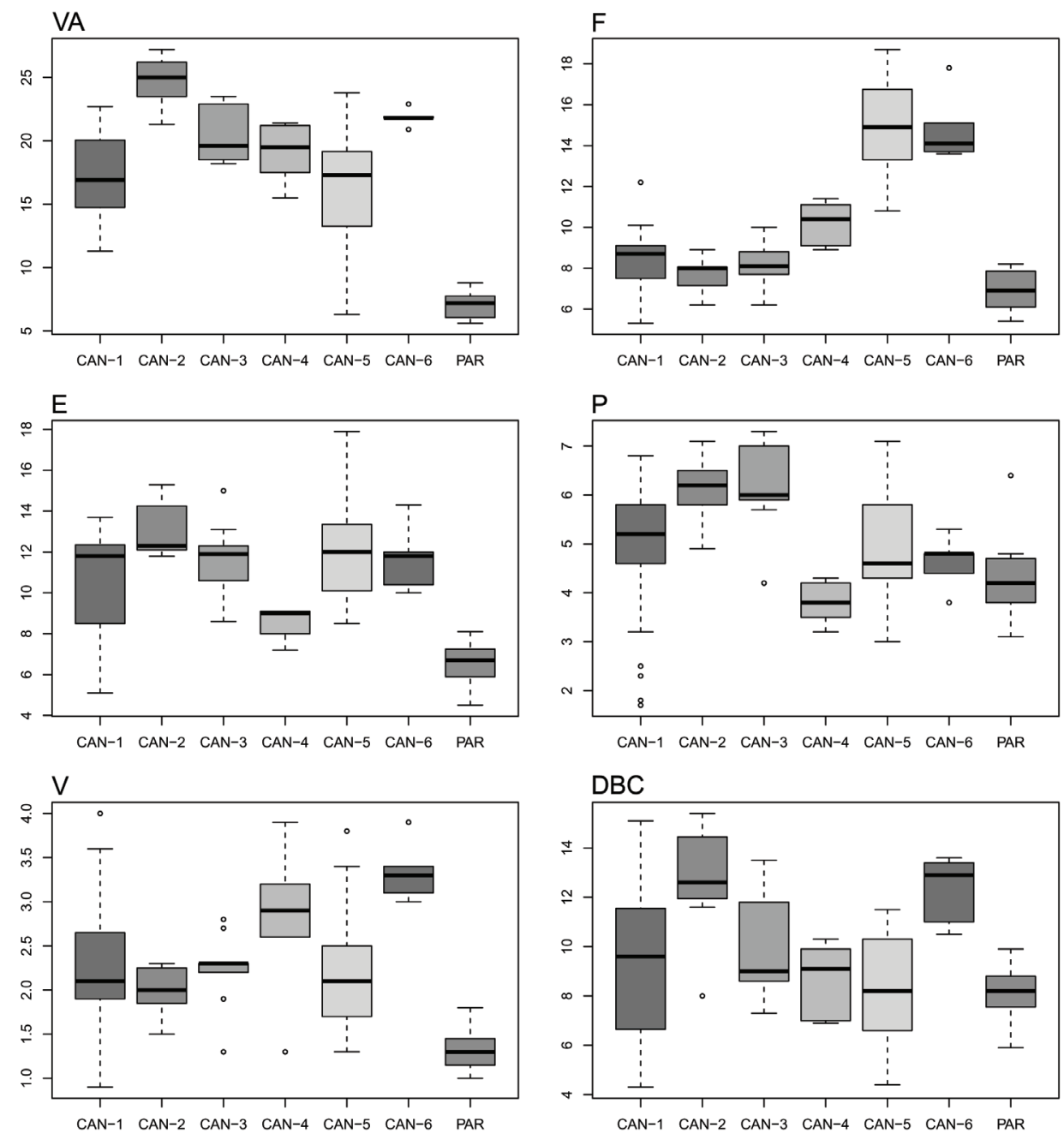

Figure 44. Box plots for genitalia characters of the seven Monacha clades investigated. The lower and upper limits of the rectangular boxes indicate the $25^{\text {th }}$ to $75^{\text {th }}$ percentile range, and the horizontal line within the boxes is the median $\left(50^{\text {th }}\right.$ percentile).

pairs, respectively). The most recognizable pairs were CAN-5 vs PAR or CAN-6 vs PAR (four significant characters), CAN-1 vs PAR or CAN-4 vs PAR (3 significant characters) and CAN-2 vs CAN-5, CAN-2 vs PAR or CAN-3 vs PAR (2 significant characters). Only one significant character distinguished CAN-1 vs CAN-2, CAN-1 vs CAN-5, CAN-1 vs CAN-6, CAN-2 vs CAN-6, CAN-3 vs CAN-5, CAN-3 vs CAN-6, CAN-4 vs CAN-5 or CAN-4 vs CAN-6 and none distinguished CAN-1 vs CAN-3, CAN- 1 vs CAN-4, CAN-2 vs CAN-3, CAN-2 vs CAN-4, CAN-3 vs CAN-4 or CAN-5 vs CAN-6 (Table 6). 


\section{Discussion}

Pieńkowska et al. (2018) found that $M$. cantiana, as usually conceived, actually consists of four distinct lineages (CAN-1, CAN-2, CAN-3 and CAN-4). Examination of a group of four additional populations from the Apuan Alps revealed two more lineages (CAN-5 and CAN-6). From a molecular point of view, they are quite distinct from each other and from all the others but from a morphological point of view they are indistinguishable from each other and only slightly distinguishable from the others.

Our present results confirm that lineages CAN-1, CAN-2 and CAN-3 can be distinguished by analysis of mitochondrial gene (COI and 16SrDNA) sequences (Figs 1, 4, 5) but not by nuclear gene (H3 and ITS2) sequences (Fig. 2). On the other hand, analysis of both nucleotide sequences (of mitochondrial and nuclear genes) showed that the CAN-4, CAN-5 and CAN-6 lineages are distinct from all the others (Figs 1-3). Moreover, these gene sequences clearly separated $M$. cantiana lineages from $M$. parumcincta.

Based on their studies of lepidopteran relationships, Hebert et al. (2003a, b) suggested that nucleotide sequences of the mitochondrial COI gene could be a universal tool for species distinction. This so called "barcode method" has since been widely used (Tautz et al. 2003; Hebert et al. 2004, 2013; Hajibabaei et al. 2007; Packer et al. 2009; Goldstein and Desalle 2011; Čandek and Kuntner 2015; Dabert et al. 2018; Yang et al. 2018, but see e.g.: Moritz and Cicero 2004; Taylor and Harris 2012). It has also been used to solve taxonomic problems in different gastropod families (Hershler et al. 2003; Remigio and Hebert 2003; Rundell et al. 2004; Elejalde et al. 2008; Duda et al. 2011; Delicado et al. 2012; Breugelmans et al. 2013; Proćków et al. 2013, 2014). However, a 3\% threshold was established arbitrarily by Hebert et al. (2003a, b) as a marker of species distinction, and in several stylommatophoran families it proves to be much higher (Davison et al. 2009; Sauer and Hausdorf 2010, 2012; Scheel and Hausdorf 2012). Moreover, we have always stressed (Pieńkowska et al. 2015, 2018) that molecular features alone are insufficient to define species but need to be supported by anatomical features.

In light of the above, we underline that the interspecific genetic distances in COI sequences between both, CAN-5 and CAN-6, and all other lineages of $M$. cantiana s.l. (CAN-5 vs CAN-1/CAN-2/CAN-3/CAN-4 - 13.3-18.2\%, CAN-6 vs CAN-1/ CAN-2/CAN-3/CAN-4 - 14.3-19.2\%; Table 5) are an order of magnitude greater than Hebert's 3\% threshold (Hebert et al. 2003a, b). It is also an order of magnitude greater than intraspecific divergence ("barcode gap", see Hebert et al. 2004; Čandek and Kuntner 2015) within CAN-5 and CAN-6 lineages, $1.3 \%$ and $1.6 \%$, respectively (Table 5). The analysis of mitochondrial COI and 16SrDNA sequences (Figs 1, 4, 5) are supported by the results of nuclear ITS2 and H3 sequences (Fig. 2). This suggests that CAN-5 and CAN-6 lineages taken together create a taxon separate from the other lineages of $M$. cantiana s.l. Despite CAN-5 differs from CAN-6 at a similarly high level (COI 12.4-14.3\%) there are no morphological differences between specimens of both lineages. The speciation of CAN-5 and CAN-6 lineages therefore seems to emerge more promptly in molecular (mitochondrial gene sequences) than in morphological (shell, genitalia) features, probably because of a rapidly evolving mitochon- 
Table 7. The best discriminant morphological characters distinguishing Monacha cantiana lineages (UD umbilicus diameter, F flagellum length).

\begin{tabular}{|c|c|c|c|c|c|c|c|c|}
\hline & & CAN-1 & $\mathrm{CAN}-2$ & CAN-3 & CAN-4 & CAN-5 & CAN-6 & PAR \\
\hline \multirow[t]{3}{*}{ UD } & mean \pm S.D. & $1.2 \pm 0.4$ & $1.3 \pm 0.2$ & $1.2 \pm 0.4$ & $1.0 \pm 0.1$ & $1.9 \pm 0.5$ & $2.6 \pm 0.4$ & $0.0 \pm 0.0$ \\
\hline & Range & $0.3-2.0$ & $1.1-1.6$ & $0.8-1.9$ & $0.8-1.1$ & $1.1-2.8$ & $2.2-3.1$ & $0.0-0.0$ \\
\hline & number of specimens & 28 & 4 & 9 & 5 & 15 & 5 & 12 \\
\hline \multirow[t]{3}{*}{ F } & mean \pm S.D. & $8.5 \pm 1.5$ & $7.6 \pm 1.0$ & $8.0 \pm 1.2$ & $10.2 \pm 1.1$ & $14.9 \pm 2.5$ & $14.9 \pm 1.7$ & $6.9 \pm 1.0$ \\
\hline & range & $5.3-12.2$ & $6.2-8.9$ & $6.2-10.0$ & $8.9-11.4$ & $10.8-18.7$ & $13.6-17.8$ & $5.4-8.2$ \\
\hline & number of specimens & 23 & 7 & 9 & 5 & 15 & 5 & 11 \\
\hline
\end{tabular}

All dimensions in $\mathrm{mm}$.

drial genome (Thomaz et al. 1996; Remigio and Hebert 2003). As mentioned above, molecular data alone cannot be used to distinguish species. It must be supported by morphological features of shells and/or genital anatomy before any decision is made about taxonomy or nomenclature.

Statistical analysis of 12 shell and six anatomical characters showed that CAN-5 and CAN-6 cannot be distinguished from each other by morphology (no character shows statistically significant differences according to Tukey's honestly significant difference test). They are only marginally distinct from CAN-1, CAN-2, CAN-3 and CAN-4, but clearly distinct from $M$. parumcincta, used for comparison: two or three characters distinguish the group CAN-5 plus CAN-6 from CAN-1, CAN-2 and CAN3; one character distinguishes CAN-5 from CAN-4; five characters distinguish CAN-6 from CAN-4; 11-14 characters distinguish the group CAN-5 plus CAN-6 from PAR. It is possible that the small sample available for lineages CAN-4 and CAN-6 (one population for each) biased comparison of these two lineages. The best discriminant characters separating the group CAN-5 plus CAN-6 from all the other lineages are umbilicus diameter (UD) and flagellum length (F). In both cases the lineages CAN-5 and CAN-6 have the highest values (Table 7).

As in the case of other lineages, the greatest bias of morphological analysis was the small sample available for lineages CAN-2, CAN-3, CAN-4 and CAN-6, which prevented a realistic account of their variability. As far as we know, this newly recognised group only occurs in the Apuan Alps and consists of two differentiated lineages (CAN-5 and CAN-6). Although examination of additional populations is desirable, intra-Apuan differentiation is also known for other organisms such as plants (Bedini et al. 2011) and animals (Zinetti et al. 2013).

Six available names have been introduced for Monacha cantiana s.l. from northwestern Tuscany (see Appendix 1). The oldest, Helix anconae, was established by Issel (1872) for specimens reported from a wide area extending northward to Arenzano in Liguria and southward to island of Elba and the Maremma of Tuscany. However, all the localities quoted are in coastal and lowland Liguria and Tuscany, while the populations including the group CAN-5 plus CAN-6 are from mountain sites. This would exclude a relationship of this nominal taxon with these lineages. 


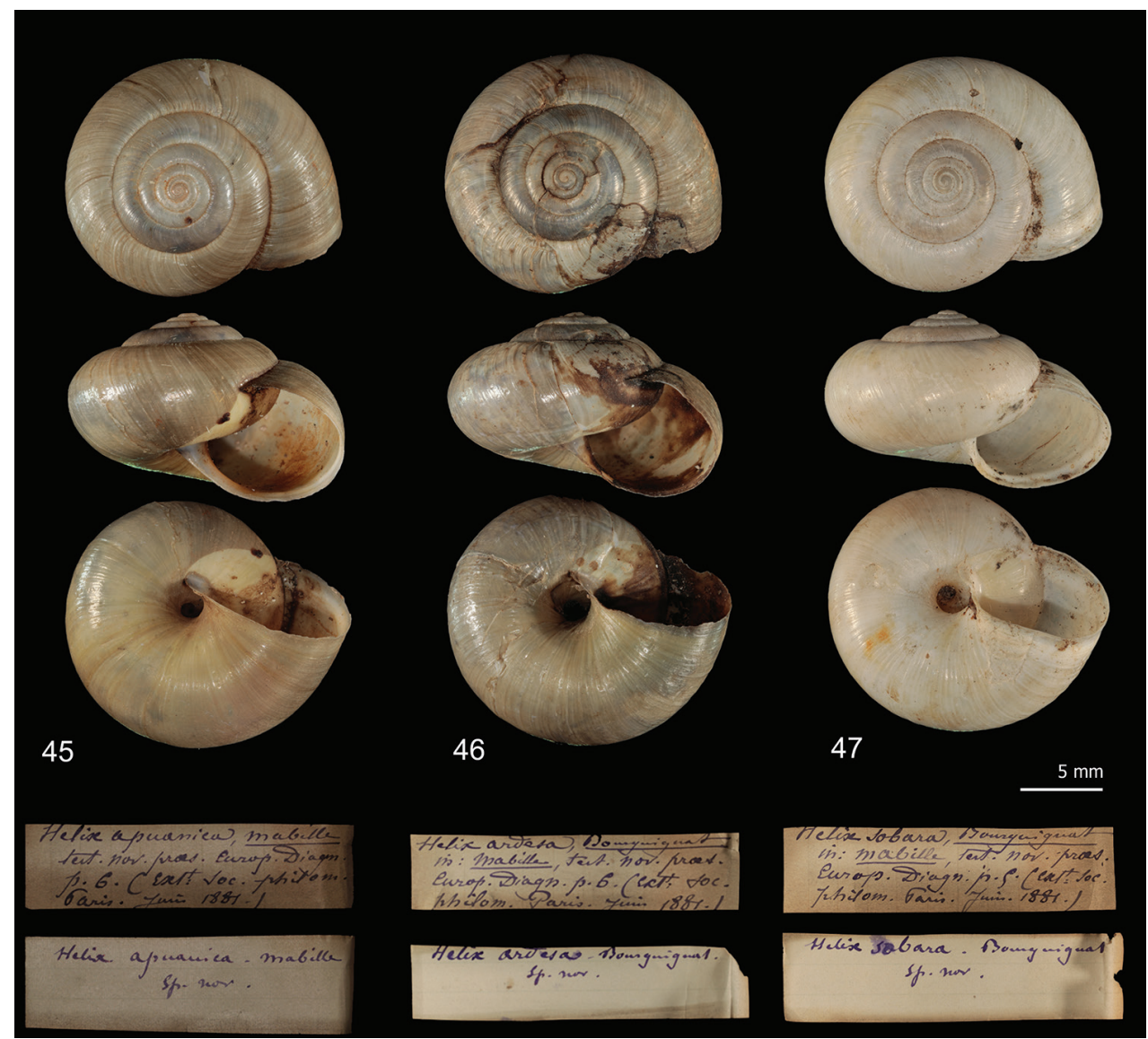

Figures 45-47. Syntypes and original labels of Monacha species from Apuan Alps established by Mabille (1881). Helix apuanica (45) (MHNG-MOLL-115981), Helix ardesa (46) (MHNG-MOLL-115982), Helix sobara (47) (MHNG-MOLL-116022) (by courtesy of E. Tardy, Muséum d'histoire naturelle, Genève, Switzerland).

All the other names were established by Mabille (1881) and De Stefani (18831888) for specimens collected in the Apuan Alps. Syntypes of the three nominal taxa introduced by Mabille (1881) are in Bourguignat's collection at the Muséum d'histoire naturelle, Genève (Switzerland) (Figs 45-47). Syntypes of the two nominal taxa established by De Stefani (1883-1888) are not known and probably lost. Umbilicus diameter of the shells of the syntypes of Mabille's species and the specimens illustrated by De Stefani is consistent for at least five of these nominal taxa with that of Monacha of the group CAN-5 plus CAN-6 (Helix sobara Mabille, 1881, Helix ardesa Mabille, 1881, Helix apuanica Mabille, 1881, Helix carfaniensis De Stefani, 1883 and Helix spallanzanii De Stefani, 1884). Mabille's three nominal taxa have precedence over those of De Stefani, and because the former were published simultaneously in the same paper, their relative precedence can only be determined by the first revisor (ICZN 1999: Art. 24). Although all three match Monacha of the group CAN-5 plus CAN-6, the best correspondence is 
with Helix sobara. Nevertheless, the availability of these names for the lineages CAN-5 and CAN-6 is somewhat difficult and not immediate. These nominal taxa were only established on shell characters, but no shell character shows statistically significant differences between CAN-5 and CAN-6. Their relationships could only therefore be established by molecular study of topotypes, but unfortunately Mabille (1881) did not quote any precise collection site. In some cases, the identity and relationships of extinct taxa have been addressed and clarified through study of ancient DNA from dried tissue (e.g. Villanea et al. 2016; Vogler et al. 2016). Unfortunately, this approach is not applicable for Mabille's syntypes because they consist only of shells devoid of any dried tissue. Thus, the case can only be solved by appeal to article 75.5 of the Code (ICZN 1999).

However, before proposing a definitive nomenclatural taxonomic setting, it is necessary to examine other populations of the group. In the meantime, these lineages should continue to be defined informally, in order to avoid creating settings based on partial and insufficient data. This approach has also been used for other gastropods, such as Carychium minimum Müller, 1774 and Carychium tridentatum (Risso, 1826) (see Weigand et al. 2012), Ancylus fluviatilis (Müller, 1774) (see Pfenninger et al. 2003; Albrecht et al. 2006) and Rumina decollata (Linnaeus, 1758) (see Prévot et al. 2016).

\section{Acknowledgements}

We are grateful to Michael Duda (Naturhistorisches Museum Wien, Austria) for providing specimens. We thank Helen Ampt (Siena, Italy) for revising the English, Giovanni Cappelli (Siena, Italy) for taking photographs of shells, Emmanuel Tardy (Muséum d'histoire naturelle, Genève, Switzerland) for providing information and photos of Mabille's syntypes in Bourguignat's collection. Many thanks also to Robert AD Cameron (University of Sheffield, United Kingdom) and to Bernhard Hausdorf (University of Hamburg, Germany) for their valuable comments on the manuscript.

\section{References}

Albrecht C, Trajanovski S, Kuhn K, Streit B, Wilke T (2006) Rapid evolution of an ancient lake species flock: freshwater limpets (Gastropoda: Ancylidae) in the Balkan Lake Ohrid. Organisms Diversity \& Evolution 6: 294-307. https://doi.org/10.1016/j.ode.2005.12.003

Alzona C (1971) Malacofauna italica. Catalogo e bibliografia dei Molluschi viventi, terrestri e d'acqua dolce. Atti della Società Italiana di Scienze Naturali e del Museo Civico di Storia Naturale di Milano 111: 1-433.

Bandelt H-J, Forster P, Röhl A (1999) Median-joining networks for inferring intraspecific phylogenies. Molecular Biology Evolution 16: 37-48. https://doi.org/10.1093/oxfordjournals. molbev.a026036

Bedini G, Carta A, Zecca G, Grassi F, Casazza G, Minuto L (2011) Genetic structure of Rhamnus glaucophylla Sommier endemic to Tuscany. Plant Systematics and Evolution 294: 273280. https://doi.org/ 10.1007/s00606-011-0469-4 
Biondi M, Urbani F, D’Alessandro P (2013) Endemism patterns in the Italian leaf beetle fauna (Coleoptera,Chrysomelidae). ZooKeys 332: 177-205. https://doi.org/10.3897/ zookeys.332.5339

Breugelmans K, Jordaens K, Adriaens E, Remon JP, Cardona JQ, Backeljau T (2013) DNA barcodes and phylogenetic affinities of the terrestrial slugs Arion gilvus and A. ponsi (Gastropoda, Pulmonata, Arionidae). ZooKeys 365: 83-104. https://doi.org/10.3897/zookeys.365.6104

Cadahia L, Harl J, Duda M, Sattmann H, Kruckenhauser L, Feher Z, Zopp L, Haring E (2014) New data on the phylogeny of Ariantinae (Pulmonata, Helicidae) and the systematic position of Cylindrus obtusus based on nuclear and mitochondrial DNA marker sequences. Journal of Zoological Systematics and Evolutionary Research 52: 163-169. https://doi.org/10.1111/jzs.12044

Carta A, Pierini B, Roma-Marzio F, Bedini G, Peruzzi L (2017) Phylogenetic measures of biodiversity uncover pteridophyte centres of diversity and hotspots in Tuscany. Plant Biosystems 152: 831-839. https://doi.org/10.1080/11263504.2017.1353550

Castresana J (2000) Selection of conserved blocks from multiple alignments for their use in phylogenetic analysis. Molecular Biology and Evolution 17: 540-552. https://doi. org/10.1093/oxfordjournals.molbev.a026334

Čandek K, Kuntner M (2015) DNA barcoding gap: reliable species identification over morphological and geographical scales. Molecular Ecology Resources 15: 268-277. https://doi. org/10.1111/1755-0998.12304

Dabert J, Mironov SV, Janiga M (2018) Two new species of the feather mite genus Analges Nitzsch, 1818 (Analgoidea: Analgidae) from accentors (Passeriformes: Prunellidae) — morphological descriptions with DNA barcode data. Systematic and Applied Acarology 23: 2288-2303. https://doi.org/10.11158/saa.23.12.2

Darriba D, Taboada GL, Doallo R, Posada D (2012) jModelTest 2: more models, new heuristics and parallel computing. Nature Methods 9: 772. https://doi.org/10.1038/nmeth.2109

Davison A, Blackie RL, Scothern GP (2009) DNA barcoding of stylommatophoran land snail: a test of existing sequences. Molecular Ecology Resources 9: 1092-1101. https://doi. org/10.1111/j.1755-0998.2009.02559x

Delicado D, Machordom A, Ramos MA (2012) Underestimated diversity of hydrobiid snails. The case of Pseudamnicola (Corrosella) (Mollusca: Caenogastropoda: Hydrobiidae). Journal of Natural History 46: 25-89. https://doi.org/10.1080/00222933.2011.623358

De Stefani C (1883-1888) Molluschi viventi nelle Alpi Apuane nel Monte Pisano e nell'Apennino adiacente. Bullettino della Società Malacologica Italiana 9 (1-5): 11-80 (1883), 9 (6-12): 81-192 (1883), 9 (13-19): 193-253 (1884), 13 (11-13): figs 1-32 [1-2] (1888).

Duda M, Sattmann H, Haring E, Bartel D, Winkler H, Harl J, Kruckenhauser L (2011) Genetic differentiation and shell morphology of Trochulus oreinos (Wagner, 1915) and T. hispidus (Linnaeus, 1758) (Pulmonata: Hygromiidae) in the northeastern alps. Journal of Molluscan Studies 77: 30-40. https://doi.org/10.1093/mollus/eyq037

Elejalde MA, Madeira MJ, Muñoz B, Arrébola JR, Gómez-Moliner BJ (2008) Mitochondrial DNA diversity and taxa delineation in the land snails of the Iberus gualterianus (Pulmonata, Helicidae) complex. Zoological Journal of the Linnean Society 154: 722-737. https://10.1111/j.1096-3642.2008.00427.x

Felsenstein J (1985) Confidence limits on phylogenies: an approach using the bootstrap. Evolution 39: 783-791. https://doi.org/10.2307/2408678 
Garbari F, Bedini G (2014) The flora of the Apuan Alps (Tuscany, Italy): survey of biosystematic investigations. Willdenowia 36: 149-155. https://doi.org/10.3372/wi.36.36112

Glez-Peña D, Gómez-Blanco D, Reboiro-Jato M, Fdez-Riverola F, Posada D (2010) ALTER: program-oriented format conversion of DNA and protein alignments. Nucleic Acids Research 38 (Web Server issue): W14-W18. https://doi.org/10.1093/nar/gkq321

Goldstein PZ, DeSalle R (2011) Integrating DNA barcode data and taxonomic practice: determination, discovery, and description. BioEssays 33: 135-147. https://doi.org/10.1002/ bies. 201000036

Hajibabaei M, Singer GAC, Clare EL, Hebert PDN (2007) Design and applicability of DNA arrays and DNA barcodes in biodiversity monitoring. BMC Biology 5: 24. https://doi. org/10.1186/1741-7007/5/24

Hall TA (1999) BioEdit: a user friendly biological sequence alignment editor and analysis program for Windows 95/98/NT. Nucleic Acids Symposium Series 41: 95-98. http://brownlab.mbio.ncsu.edu/JWB/papers/1999Hall1.pdf

Hasegawa M, Kishino H, Yano T (1985) Dating the human-ape split by a molecular clock of mitochondrial DNA. Journal of Molecular Evolution 22: 160-174. https://doi. org/10.1007/BF02101694

Hebert PDN, Cywinska A, Ball SL, deWaard JR (2003a) Biological identifications through DNA bardcodes. Proceedings of the Royal Society B: Biological Sciences 270: 313-321. https://doi.org/10.1098/rspb.2002.2218

Hebert PDN, deWaard JR, Zakharov EV, Prosser SWJ, Sones JE, McKeown JAT, Mantle B, La Salle J (2013) DNA 'barcode blitz': rapid digitization and sequencing of a natural history collection. PLoS One 8: e68535. https://doi.org/10.1371/journal.pone.0068535

Hebert PDN, Ratnasingham S, deWaard JR (2003b) Barcoding animal life: cytochrome c oxidase subunit 1 divergences among closely related species. Proceedings of the Royal Society B: Biological Sciences 270 (Suppl. 1): 596-599. https://doi.org/10.1098/rsbl.2003.0025

Hebert PDN, Stoeckle MY, Zemlak TS, Francis CM (2004) Identification of birds through DNA barcodes. PLoS Biology 10: e312 (1657-1663). https://doi.org/10.1371/journal.pbio.0020312

Hershler R, Liu HP, Thompson FG (2003) Phylogenetic relationships of North American nymphophiline gastropods based on mitochondrial DNA sequences. Zoologica Scripta 32: 357-366. https://doi.org/10.1046/j.1463-6409.2003.00115.x

ICZN (International Commission on Zoological Nomenclature) (1999) International Code of Zoological Nomenclature, 4th Edition. The International Trust for Zoological Nomenclature, London, 306 pp.

Issel A (1872) Appendice al Catalogo dei Molluschi raccolti nella provincia di Pisa. Atti della Società Italiana di Scienze Naturali 15: 58-76.

Kimura M (1980) A simple method for estimating evolutionary rate of base substitutions through comparative studies of nucleotide sequences. Journal of Molecular Evolution 16: 111-120. https://doi.org/10.1007/bf01731581

Kruckenhauser L, Duda M, Bartel D, Sattmann H, Harl J, Kirchner S, Haring E (2014) Paraphyly and budding speciation in the hairy snail (Pulmonata, Hygromiidae). Zoologica Scripta 43: 273-288. https://doi.org/10.1111/zsc.12046 
Kumar S, Stecher G, Tamura K (2016) MEGA7: Molecular Evolutionary Genetics Analysis version 7.0 for bigger datasets. Molecular Biology and Evolution 33: 1870-1874. https:// doi.org/10.1093/molbev/msw054

Lanza B (1997) La fauna endemica delle Alpi Apuane (Toscana, Italia). Atti della Società Toscana di Scienze Naturali Residente in Pisa Memorie Serie B 103: 17-37.

Linnaeus C (1758) Systema naturæ per regna tria naturæ, secundum classes, ordines, genera, species, cum characteribus, differentiis, synonymis, locis. Editio decima, reformata. Tomus I. Salvius, Holmiæ, $4+824$ pp.

Mabille J (1881) Testarum novarum praesertim europæarum diagnoses. Bulletin de la Société Philomathique de Paris Septième Série 5: 122-130. https:/www.biodiversitylibrary.org/ item/98733\#page/136

Manganelli G, Salomone N, Giusti F (2005) A molecular approach to the phylogenetic relationships of the western palaearctic Helicoidea (Gastropoda: Stylommatophora). Biological Journal of Linnean Society London 85: 501-512. https://doi.org/10.1111/j.10958312.2005.00514.x

Montagu G (1803) Testacea Britannica, or, Natural history of British shells, marine, land, and fresh-water, including the most minute: systematically arranged and embellished with figures. 2 vols, Romsey, London, xxxvii + 606 pp.

Moritz C, Cicero C (2004) DNA barcoding: promise and pitfalls. PLoS Biology 2(10): e354. https://doi.org/10.1371/journal.pbio.0020354

Müller OF (1774) Vermium terrestrium et fluviatilium, seu animalium infusiorium, helminthicorum, et testaceorum, non marinorum, succinct historia. Vol. II. Heineck \& Faber, Havniae et Lipsiae, xxxvi + $214+10$ pp.

Nei M, Kumar S (2000) Molecular Evolution and Phylogenetics. Oxford University Press, New York, $352 \mathrm{pp}$.

Neiber MT, Hausdorf B (2015) Phylogeography of the land snail genus Circassina (Gastropoda: Hygromiidae) implies multiple Pleistocene refugia in the western Caucasus region. Molecular Phylogenetics and Evolution 93: 129-142. https://doi.org/10.1016/j.ympev.2015.07.012

Orsenigo S, Montagnani C, Fenu G, Gargano D, Peruzzi L, Abeli T, Alessandrini A, Bacchetta G, Bartolucci F, Bovio M, Brullo C, Brullo S, Carta A, Castello M, Cogoni D, Conti F, Domina G, Foggi B, Gennai M, Gigante D, Iberite M, Lasen C, Magrini S, Perrino EV, Prosser F, Santangelo A, Selvaggi A, Stinca A, Vagge I, Villani M, Wagensommer R, Wilhalm T, Tartaglini N, Duprè E, Blasi C, Rossi G (2018) Red Listing plants under full national responsibility: extinction risk and threats in the vascular flora endemic to Italy. Biological Conservation 224: 213-222. https://doi.org/10.1016/j.biocon.2018.05.030

Packer L, Grixti JC, Roughley RE, Hanner R (2009) The status of taxonomy in Canada and the impact of DNA barcoding. Canadian Journal of Zoology 87: 1097-1110. https://doi. org/10.1139/Z09-100

Pfenninger M, Staubbach S, Albrecht C, Streit B, Schwenk K (2003) Ecological and morphological differentiation among cryptic evolutionary lineages in freshwater limpets of the nominal form-group Ancylus fluviatilis (O.F. Müller 1774). Molecular Ecology 12: 27312745. https://doi.org/10.1046/j.1365-294X.2003.01943.x 
Pieńkowska JR, Giusti F, Manganelli G, Lesicki A (2015) Monacha claustralis (Rossmässler 1834) new to Polish and Czech malacofauna (Gastropoda: Pulmonata: Hygromiidae). Journal of Conchology 42: 79-93.

Pieńkowska JR, Lesicki A (2018) A note on status of Galba occulta Jackiewicz, 1959 (Gastropoda: Hygrophila: Lymnaeidae). Folia Malacologica 26: 231-247. https://doi.org/10.12657/ folmal.026.029

Pieńkowska JR, Manganelli G, Giusti F, Hallgass A, Lesicki A (2018) Exploring Monacha cantiana (Montagu, 1803) phylogeography: cryptic lineages and new insights into the origin of the English populations (Eupulmonata, Stylommatophora, Hygromiidae). ZooKeys 765: 1-41. https://doi.org/10.3897/zookeys.765.24386

Prévot V, Jordaens K, Sonet G, Backeljau T (2013) Exploring species level taxonomy and species delimitation methods in the facultatively self-fertilizing land snail genus Rumina (Gastropoda: Pulmonata). PLoS One 8(4): e60736. https://doi.org/10.1371/journal.pone.0060736

Proćków M, Mackiewicz P, Pieńkowska JR (2013) Genetic and morphological studies of species status for poorly known endemic Trochulus phorochaetius (Bourguignat, 1864) (Gastropoda: Pulmonata: Hygromiidae), and its comparison with closely related taxa. Zoological Journal of Linnean Society 169: 124-143. https://doi.org/10.1111/zoj.12048

Proćków M, Strzała T, Kuźnik-Kowalska E, Mackiewicz P (2014) Morphological similarity and molecular divergence of Trochulus striolatus and T. montanus, and their relationship to sympatric congeners (Gastropoda: Pulmonata: Hygromiidae). Systematics and Biodiversity 12: 366-384. https://doi.org/10.1080/14772000.2014.925986

Razkin O, Gomez-Moliner BJ, Prieto CE, Martinez-Orti A, Arrebola JR, Munoz B, Chueca LJ, Madeira MJ (2015) Molecular phylogeny of the western Palaearctic Helicoidea (Gastropoda, Stylommatophora). Molecular Phylogenetics and Evolution 83: 99-117. https:// doi.org/10.1016/j.ympev.2014.11.014

Remigio EA, Hebert PDN (2003) Testing the utility of partial COI sequences for phylogenetic estimates of gastropod relationships. Molecular Phylogenetics and Evolution 29: 641-647. https://doi.org/10.1016/S1055-7903(03)00140-4

Risso A (1826) Histoire naturelle des principales productions de l'Europe méridionale et particulièrement de celles des environs de Nice et des Alpes Maritimes. Tome quatrième. Levrault, Paris, $10+439+12$ pp. https://doi.org/10.5962/bhl.title.58984

Ronquist F, Huelsenbeck JP (2003) MRBAYES 3: Bayesian phylogenetic inference under mixed models. Bioinformatics 19: 1572-1574. https://doi.org/10.1093/bioinformatics/btg180

Rossmässler EA (1834) Diagnoses conchyliorum terrestrium et fluviatilum. Zugleich zu Fascikeln natürlicher Exemplare. II Heft. No. 21-40. Arnold, Dresden \& Leipzig, 8 pp. https://doi.org/10.5962/bhl.title.10380

Rundell RJ, Holland BS, Cowie RH (2004) Molecular phylogeny and biogeography of the endemic Hawaiian Succineidae (Gastropoda: Pulmonata). Molecular Phylogenetics and Evolution 31: 246-255. https://doi.org/10.1016/j.ympev.2003.07.014

Saitou N, Nei M (1987) The neighbor-joining method: A new method for reconstructing phylogenetic trees. Molecular Biology and Evolution 4: 406-425. https://doi.org/10.1093/ oxfordjournals.molbev.a040454 
Sauer J, Hausdorf B (2010) Reconstructing the evolutionary history of the radiation of the land snail genus Xerocrassa on Crete based on mitochondrial sequences and AFLP markers. BMC Evolutionary Biology 10: 299. https://doi.org/10.1186/1471-2148-10-299

Sauer J, Hausdorf B (2012) A comparison of DNA-based methods for delimiting species in a Cretan land snail radiation reveals shortcomings of exclusively molecular taxonomy. Cladistics 28: 300-316. https://doi.org/10.1111/j.1096-0031.2011.00382.x

Scheel BM, Hausdorf B (2010) Survival and differentiation of subspecies of the land snail Charpentieria itala in mountain refuges in the Southern Alps. Molecular Ecology 21:3794-3808.

Talavera G, Castresana J (2007) Improvement of phylogenies after removing divergent and ambiguously aligned blocks from protein sequence alignments. Systematic Biology 56: 564-577. https://doi.org/10.1080/10635150701472164

Tamura K (1992) Estimation of the number of nucleotide substitutions when there are strong transition-transversion and G+C-content biases. Molecular Biology and Evolution 9: 678687. https://doi.org/10.1093/oxfordjournals.molbev.a040752

Tautz D, Arctander P, Minelli A, Thomas RH, Vogler AP (2003) A plea for DNA taxonomy. Trends in Ecology \& Evolution 18: 70-74. https://doi.org/10.1016/S0169-5347(02)00041-1 Taylor HR, Harris WE (2012) An emergent science on the brink of irrelevance: a review of the past 8 years of DNA barcoding. Molecular Ecology Resources 12: 377-388. https://doi. org/10.1111/j.1755-0998.2012.03119.x

Thompson JD, Higgins DG, Gibson TJ (1994) CLUSTAL W: improving the sensitivity of progressive multiple sequence alignment through sequence weighting, position specific gap penalties and weight matrix choice. Nucleic Acids Research 22: 4673-4680. https://doi. org/10.1093/nar/22.22.4673

Thomaz D, Guiller A, Clarke B (1996) Extreme divergence of mitochondrial DNA within species of pulmonate land snails. Proceedings of Royal Society B: Biological Sciences 263: 363-368. https://doi.org/10.1098/rspb.1996.0056

Villanea FA, Parent CE, Kemp BM (2016) Reviving Galápagos snails: ancient DNA extraction and amplification from shells of probably extinct endemic land snails. Journal of Molluscan Studies 82: 449-456. https://doi.org/10.1093/mollus/eyw011

Vogler RE, Beltramino AA, Strong EE, Rumi A, Peso JG (2016) Insights into the evolutionary history of an extinct South American freshwater snail based on historical DNA. PLoS One 11 (12): e0169191. https://doi.org/10.1371/journal.pone.0169191

Weigand AM, Pfenninger M, Jochum A, Klussmann-Kolb A (2012) Alpine crossroads or origin of genetic diversity? Comparative phylogeography of two sympatric microgastropod species. PLoS One 7 (5): e37089. https://doi.org/10.1371/journal.pone.0037089

Yang QQ, Liu SW, Yu XP (2018) Research progress on DNA barcoding analysis methods. Ying Yong Sheng Tai Xue Bao (Chinese Journal of Applied Ecology) 29: 1006-1014. [in Chinese with English abstract]

Zinetti F, Dapporto L, Vanni S, Magrini P, Bartolozzi L, Chelazzi G, Ciofi C (2013) Application of molecular genetics and geometric morphometrics to taxonomy and conservation of cave beetles in central Italy. Journal of Insect Conservation 17: 921-932. https://doi. org/10.1007/s10841-013-9573-9 


\section{Appendix I}

\section{Nominal taxa of Monacha cantiana group established from north-western Tuscany}

Helix anconae Issel, 1872: 63-65

Type locality: "[...] Montecatini, Val di Nievole, non lungi da Cecina nella Maremma toscana, nell'isola d'Elba, a Genova, ad Arenzano ed in altre località della Toscana e della Liguria."

Type material: probably lost.

Status: listed as subspecies of Monacha cantiana by Alzona (1971).

Helix sobara Mabille, 1881: 126-127

Type locality: "in Alpibus Apuanis."

Type material: one syntype (MHNG-MOLL-116022) is in Bourguignat's collection at Muséum d'histoire naturelle, Genève (Switzerland).

Note: assigned to J. Bourguignat.

Status: listed as junior synonym of Monacha cantiana anconae by Alzona (1971).

Helix ardesa Mabille, 1881: 127

Type locality: "in Alpibus Apuanis."

Type material: one syntype (MHNG-MOLL-115982) is in Bourguignat's collection at Muséum d'histoire naturelle, Genève (Switzerland).

Note: assigned to J. Bourguignat.

Status: listed as junior synonym of Monacha cantiana anconae by Alzona (1971).

Helix apuanica Mabille, 1881: 127-128

Type locality: "in Alpibus Apuanis."

Type material: one syntype (MHNG-MOLL-115981) is in Bourguignat's collection at Muséum d'histoire naturelle, Genève (Switzerland).

Note: assigned to J. Bourguignat.

Status: listed as junior synonym of Monacha cantiana anconae by Alzona (1971).

Helix (Monacha) carfaniensis De Stefani, 1883: 53-54 (as "Helix carfaniensis"), 1884: 231, 1888: fig. 8.

Type locality: Serchio Valley, Vagli. De Stefani (1884: 231) stated that the type is from Serchio Valley and depicted a shell from Vagli.

Type material: probably lost.

Status: listed as junior synonym of Monacha cantiana anconae by Alzona (1971).

Helix (Monacha) carfaniensis subvar. minor De Stefani, 1883: 54 (as "subvar. minor")

Type locality: "App[ennino]. San Pellegrino 1464 [m]."

Type material: probably lost.

Note: First reported by De Stefani (1875: 43-44) as Helix cantiana var. minor Albers.

Status: not available because this name denotes an infrasubspecific taxon. 
Helix (Eulota) cemenelea forma isselii De Stefani, 1883: 55-59 (as "Helix cemenelea forma issellii")

Type locality: see Helix spallanzanii below.

Type material: probably lost.

Status: not available because junior homonym of Helix isseli Morelet, 1872; renamed as Helix spallanzanii De Stefani, 1884.

Helix spallanzanii De Stefani, 1884: 208, 231, 1888: fig. 7.

Type locality: Apuan Alps, Vagli. De Stefani (1884: 231) stated that the type is from Apuan Alps and depicted a shell from Vagli.

Type material: probably lost.

Status: new name for Helix (Eulota) cemenelea forma isselii De Stefani, 1883, junior homonym of Helix isseli Morelet, 1872.

Status: listed as junior synonym of Monacha cantiana anconae by Alzona (1971). 